\title{
Mechanical and Deformation Characteristics and Optimization of Support Parameters for Superlarge-Span Tunnel: A Case Study from Laohushan Tunnel
}

\author{
Yanbin Luo $\mathbb{D}^{1},{ }^{1}$ Jianxun Chen $\mathbb{D}^{1},{ }^{1}$ Zhou Shi $\mathbb{D}^{1},{ }^{1}$ Shaoqiang Zhang, ${ }^{2}$ Weiwei Liu $\mathbb{D},{ }^{1}$ \\ and $\mathrm{Yao} \mathrm{Li}^{1}$ \\ ${ }^{1}$ School of Highway, Chang'an University, Xi'an 710064, Shaanxi, China \\ ${ }^{2}$ China Power Construction Road and Bridge Group Co., Ltd, Beijing 100089, China \\ Correspondence should be addressed to Jianxun Chen; chenjx1969@chd.edu.cn and Weiwei Liu; liuwwchd@163.com
}

Received 3 March 2020; Revised 14 June 2020; Accepted 6 July 2020; Published 31 July 2020

Academic Editor: Jia-wen Zhou

Copyright (c) 2020 Yanbin Luo et al. This is an open access article distributed under the Creative Commons Attribution License, which permits unrestricted use, distribution, and reproduction in any medium, provided the original work is properly cited.

\begin{abstract}
In the new construction or reconstruction of expressway projects, the number of highway twin tunnels with eight lanes is increasing. However, there are no corresponding design support parameters and measures in the current technical specifications for tunnel design and construction in China. In Laohushan superlarge-span highway tunnel with single hole and four lanes, the deformation behavior and mechanical characteristics of support structures are measured and analyzed. The monitoring results indicated that the deformation of tunnel structure mainly experienced three stages: rapid deformation, slow deformation, and stable deformation, and finally reached a relatively stable state; the structure stress of primary support and secondary lining increases sharply at first and then tends to be stable gradually with the gradual construction of each excavation part in the tunnel; the stress of each measuring point at the steel rib is less than the yield limit of steel rib $(235 \mathrm{MPa})$, and the support structure is safe and stable in the process of tunnel construction. Then, the structure safety of primary support under different support parameters is simulated and calculated by numerical simulation with Grade IV rock mass, and the reasonable support parameters for Laohushan highway tunnel are studied considering the structural safety and engineering economy. It is suggested to use the H175type steel sets with a distance of $80 \mathrm{~cm}$ and C25 shotcrete with a thickness of $26 \mathrm{~cm}$. The results could provide reference for similar tunnel projects and provide a basis for the design specification and construction standards for superlarge-span tunnels.
\end{abstract}

\section{Introduction}

In recent years, along with the implementation of China's "The Belt and The Road" strategic plan and the rapid development of national economy, infrastructure construction meets the new development upsurge. There are more and more large-scale underground structures in new construction or expansion projects to stimulate economic development potential, such as underground oil depots and largescale hydropower projects, as well as traffic tunnel engineering [1-5]. With the rapid development of economy and the acceleration of urbanization, the number of motor vehicles has been increasing and traffic volume has been increasingly saturated. Traffic congestion has seriously restricted the development of road traffic [6-8]. Because the construction of tunnel project is irreversible and the traffic routes are difficult to reappear once occupied, there are more and more single-hole four-lane highway superlarge-span tunnels in new construction and reconstruction projects. Compared to the highway tunnel with three or two lanes, superlarge-span tunnel has the advantages of increasing vehicle speed, shortening mileage, and saving energy and time [9, 10]. In 2010, The Road Design Manual Tunnels $[11,12]$, issued by the Ministry of Land, Transport and Maritime Affairs of South Korea, detailed the design support parameters of superlarge-span highway tunnels. At present, more and more superlarge-span tunnels have been built in China, but the corresponding standard for the design support parameters has not been added in Specifications for Design of Highway Tunnel (JTG 3370.1-2018) [13] in China. Construction of superlarge-span highway tunnels followed the design standards of two- or three-lane tunnel standard 
combining the engineering analogy method. Some scholars have done some research on the deformation and mechanical law of support structure in the process of tunnel construction [14-19], but most of the research is based on small- and medium-span tunnels. There is little research on the mechanical and deformation characteristics of the support structure and the selection of reasonable support parameters in the process of superlarge-span tunnel construction.

Many scholars have studied the characteristics of tunnel support structure and the mechanical laws in the construction process and optimized the design parameters of the support structure [20-23]. However, these research studies are only limited to the two-lane tunnel, and these parameters are no longer applicable for the superlarge-span tunnel because the stability of the tunnel structure decreases with the excavation span increasing. Numerical simulation is widely used in the construction optimization of large underground caverns and tunnels. Jiang et al. used the numerical simulation and artificial intelligence method combining bionic particle swarm optimization algorithm and support vector machine to make the global optimization for the excavation process of Laxiwa cavern group [24]. Wang et al. analyzed the adaptability of the primary support arch cover method in large-span tunnel by field monitoring and numerical simulation. The numerical simulation results show that the primary support arch cover method has advantages in settlement control, plastic zone distribution, and support structure safety for large-span tunnel [25]. Gao et al. and Huang, based on geotechnical engineering inversion theory, proposed reasonable support parameters in single tunnel construction with four lanes by comparing support parameters to the optimized support parameters [23, 26]. Huang stated that for the IV grade rock section, the primary support thickness is $22 \mathrm{~cm}$, and the secondary lining is $50 \mathrm{~cm}$ thick [26]. To control the deformation of soft rock and ensure construction safety, Gao et al. proposed a support structure involving weakening the anchor bolts while enhancing the rigidity and strength of primary supports [23]. Hou conducted some tests including the rock mechanical test, bearing plate test, numerical back analysis, field test of shear strength, and numerical simulation to study the reasonable excavation method and parameters of four-lane road tunnel in Class IV surrounding rock. Research showed that normal elasticity modulus of rock mass was obviously less than transverse elasticity modulus, and it has remarkable transverse isotropy. Settlement of vault was the main deformation in horizontal layered surrounding rock [27].

$\mathrm{Wu}$ and $\mathrm{He}$ simulated the structure form and support parameters of the superlarge-span tunnel through numerical simulation, and a reasonable support method for the fourlane highway tunnel was also proposed $[28,29]$. Wu states that the circumferential spacing of the anchors in the case of Class IV surrounding rock is $0.8 \sim 1 \mathrm{~m}$, and it is arranged in the form of plum [28]. Han et al. proposed a reasonable form of support for special strata by on-site monitoring and numerical simulation. The result shows that the deformation amount and deformation rate of surrounding rock can be effectively controlled by adopting quasicircular section, especially the horizontal convergence deformation [30]. Min et al. used the numerical simulation method to analyze the construction safety of four-lane shallow-buried loess tunnel and optimize construction schemes constructed by threebench seven-step excavation method (TSEM), central diaphragm, cross diaphragm, and double side-drift method (DSDM). They proposed that DSDM is recommended for the strict deformation requirement, giving priority to TSEM for allowing the large deformation [31]. Chen et al. and Luo et al. summarized the general rule that indicated the system bolt will not affect the safety and stability of the primary support structure in the tunnel with weak rock. The optimal support parameters of the superlarge-span tunnel are always obtained by numerical simulation or model test [32, 33]. Massone and Nazar experimentally evaluated the use of steel or polypropylene fibers in shotcrete as a partial replacement for the traditional reinforcement of electrowelded mesh used at the tunnel support for the subway in Santiago (Chile). The results showed that the safety factors implicit in the traditional design are high, which caused the parameters of the support structure to be too conservative and led to a great waste of materials [34].

Previous research studies generally aimed at single support parameter under the specific stratum, and the applicability in another project is limited. Therefore, it is necessary to get the appropriate support parameters for superlarge-span tunnels [35-38]. This paper analyzes the deformation behavior and mechanical characteristics for primary support structure in the construction process of Laohushan superlarge-span tunnel. At the same time, starting from the structure parameters of tunnel primary support, this paper uses the method of numerical simulation to analyze and calculate the internal force and safety factor of tunnel structure under different primary support parameters and studies the reasonable types of support structure and the corresponding support parameters of superlarge-span highway tunnel in Grade IV rock mass based on the structural safety and engineering economy. The research results were used as reference for optimizing the design parameters and improve the construction technology of Laohushan Tunnel. At the same time, it could also provide reference for the design specifications and standards for superlarge-span highway tunnels in similar projects.

\section{Project Overview and Monitoring Program}

Laohushan Highway Twin Tunnel with eight lanes is located in Jinan City of Shandong Province. The geographical location of Laohushan tunnel is shown in Figure 1. The length of the right line of tunnel is $1740 \mathrm{~m}$, the length of left line is $1888 \mathrm{~m}$, and the maximum excavation span is $20.008 \mathrm{~m}$, which belongs to the superlarge-span highway tunnel. The support form of Laohushan Tunnel is a composite lining structure. The actual support parameters of tunnel are shown in Table 1 . The stratum between the $\mathrm{YK} 2+444$ section and YK2 +453 section of Laohushan tunnel is the paleoweathering crust of the lower Ordovician (O1) of Paleozoic, and the lithology is yellow paleoresidual gravelly soil and gravelly block soil. The lithology of rock mass in the 


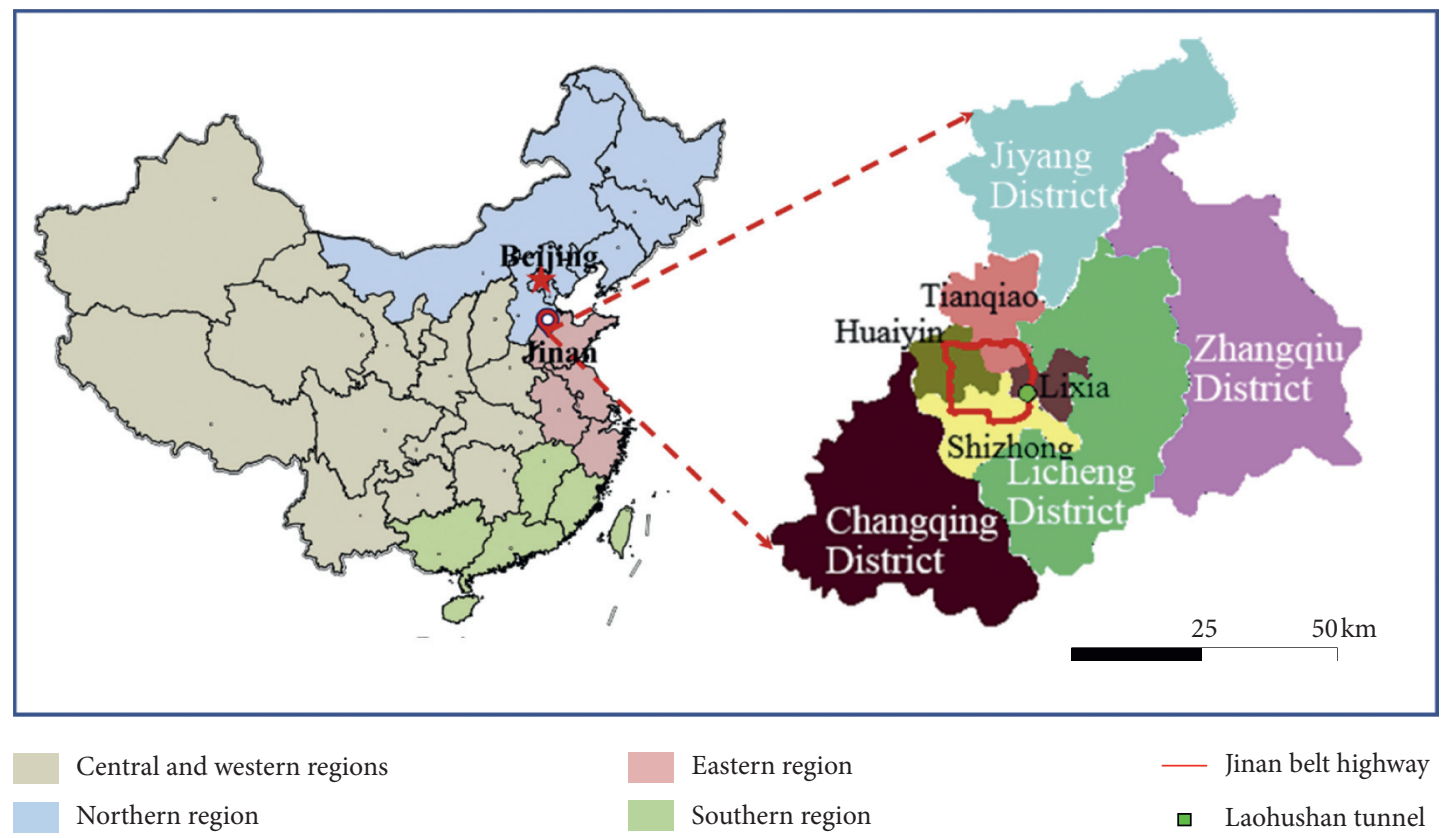

FiguRE 1: Geographical location of Laohushan tunnel in China.

TABle 1: Support parameters of tunnel.

\begin{tabular}{lccccc}
\hline \multirow{2}{*}{$\begin{array}{l}\text { Support type } \\
\end{array}$} & Steel rib & Steel ribs spacing $(\mathrm{m})$ & C25 shotcrete thickness $(\mathrm{cm})$ & Bolt & Secondary lining \\
\hline $\begin{array}{l}\text { Strengthening } \\
\begin{array}{l}\text { Section in grade } \\
\text { IV rock mass }\end{array}\end{array}$ & $\mathrm{H} 200 \times 200$ & 0.75 & 28 & Local bolts & C 30 concrete $55 \mathrm{~cm}$ thick \\
\hline
\end{tabular}

test section is poor as a whole, including strongly weathered limestone and nonweak intercalation, with the relatively hard rock and the relatively developed joint fissures. There are a lot of loess and yellow mud in the soft interlayer with low strength, low hammering degree, and poor interlayer combination, which is easy to soften when soaked in water. The self-stability ability and the overall stability of rock mass in tunnel face are general. The tunnel foundation is slightly weathered limestone with hard rock and good integrity. The rock mass condition of tunnel is shown in Figure 2.

To ensure the completion of tunnel project on schedule, a temporary support middle diaphragm was used in the construction of Laohushan Tunnel. The upper bench CD method was mainly used in the construction of the tunnel. The new construction method can not only effectively control the deformation of tunnel but also speed up the construction progress, improving the construction efficiency greatly. The method is shown in Figure 3.

Based on the characteristics of the engineering geological conditions and construction technology of Laohushan Tunnel in Grade IV rock mass section, three test sections were selected to carry out deformation monitoring, and one section was selected to carry out stress monitoring as shown in Table 2 . The fast, accurate, and reliable testing methods are used to track and measure the key sections in tunnel construction. Detailed measuring items and methods are listed in Table 3. The layout of monitoring points is shown in Figure 4.

\section{Mechanical Characteristics Analysis of Support Structure}

3.1. Tunnel Deformation Characteristics. The layout and number of deformation monitoring points are shown in Figure 4, and the deformation monitoring results are shown in Table 4. The field monitoring data of tunnel and the specific conditions during construction showed that the laws of each monitoring section were basically the same. Only the $\mathrm{YK} 2+449$ section is selected as an example for analysis, as shown in Figures 5 and 6.

Table 4 shows that the deformation value at YK2 +449 section was small, and the maximum settlement was $21.2 \mathrm{~mm}$, accounting for $15 \%$ of the permissible maximum value, which shows that the primary support can control the tunnel deformation effectively. The trend of vault settlement and clearance convergence were basically consistent with time. In the early stage, the settlement of crown increased rapidly. It tended to be stable after 20 days of primary support completion. When the temporary support was removed, the constraint on the primary support structure of arch was lifted. The settlement at the vault (points 1 and 5) fluctuated slightly and then stabilized. The vault settlement was slightly 

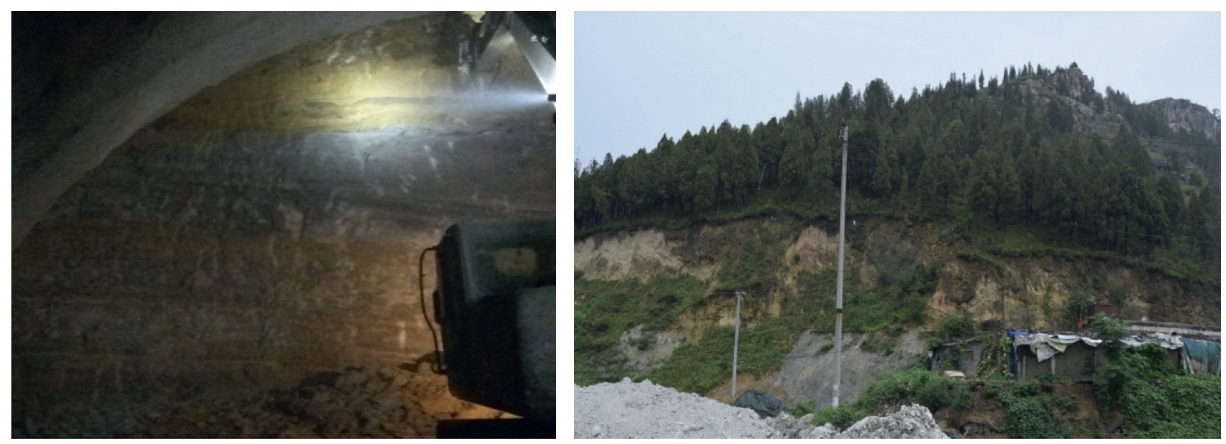

FIGURE 2: Rock mass condition of Grade IV strengthening section in Laohushan tunnel.

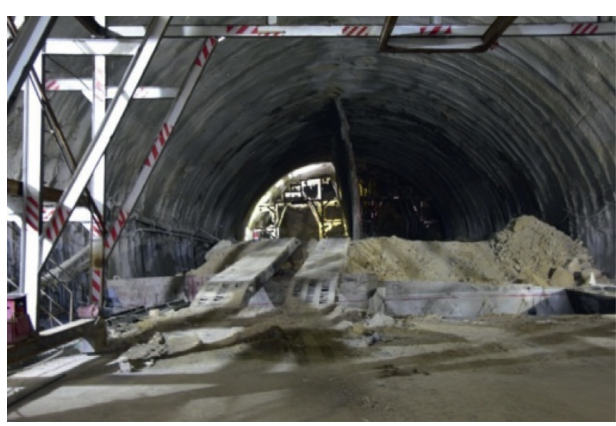

(a)

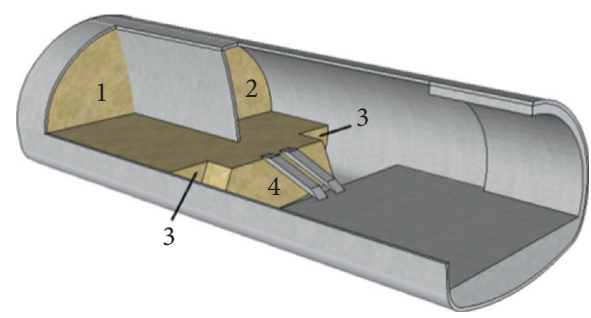

(b)

Figure 3: The upper bench CD method. (a) Site photo of the upper bench CD method. (b) Three dimensional schematic diagram.

TABLE 2: Site section monitoring scheme.

\begin{tabular}{|c|c|c|c|c|c|c|c|}
\hline Lining type & $\begin{array}{l}\text { Construction } \\
\text { method }\end{array}$ & $\begin{array}{c}\text { Stress } \\
\text { monitoring } \\
\text { section }\end{array}$ & $\begin{array}{c}\text { Deformation } \\
\text { monitoring section }\end{array}$ & $\begin{array}{c}\text { Buried } \\
\text { depth }(m)\end{array}$ & $\begin{array}{l}\text { Space } \\
(\mathrm{m})\end{array}$ & Lithology & $\begin{array}{c}\text { Component } \\
\text { quantity }\end{array}$ \\
\hline \multirow{3}{*}{$\begin{array}{l}\text { Strengthening } \\
\text { Section in } \\
\text { grade } \\
\text { IV rock mass }\end{array}$} & \multirow{3}{*}{$\begin{array}{l}\text { Upper bench CD } \\
\text { method }\end{array}$} & \multirow{3}{*}{$\mathrm{YK} 2+449$} & $\mathrm{YK} 2+444$ & & & \multirow{3}{*}{$\begin{array}{l}\text { Gravel soil + strongly } \\
\text { weathered limestone }\end{array}$} & \multirow{3}{*}{80} \\
\hline & & & $\mathrm{YK} 2+449$ & 165 & 31 & & \\
\hline & & & $\mathrm{YK} 2+453$ & & & & \\
\hline
\end{tabular}

larger than clearance convergence. After the temporal curve was stabilized, the bottom pilot excavation and the invert construction had no obvious influence on the settlement curve. Due to the influence of blasting vibration and other factors in the construction process, the monitoring data fluctuated slightly. After the inverted arch was installed and the support structure was closed into a ring, the deformation of primary support structure tended to be stable gradually. Both settlement and convergence showed the characteristics from rapid growth to slow change and finally to stability. The monitoring results indicated that the deformation of tunnel structure mainly experienced three stages: rapid deformation, slow deformation, and stable deformation, and finally reached a relatively stable state; the primary support structure could effectively constrain the deformation of rock mass, and the support structure was also safe and reliable.
3.2. Tunnel Stress Characteristics. The layout of measuring points in the stress monitoring section is shown in Figure 4. The stress monitoring points are named according to the rule of " element name + layout number + part number." Positive value indicated that the structure is in compression, and negative value meant the structure is in tension.

3.2.1. Shotcrete Stress. The stress distribution of shotcrete is shown in Figure 7, and the temporal curve is shown in Figure 8 .

It can be seen from Figures 7 and 8 that the stress distribution of shotcrete in $\mathrm{YK} 2+449$ section is uneven, and the whole shotcrete is in compression. The arch stress was greater than that of the side wall, and the force on the right side of section was slightly larger than that of the left 
TABLE 3: Field test items and measurement methods.

\begin{tabular}{|c|c|c|c|c|c|}
\hline Number & Measurement items & Measurement instrument & $\begin{array}{l}\text { Instrument } \\
\text { specifications }\end{array}$ & \multicolumn{2}{|c|}{ Measurement frequency } \\
\hline 1 & Horizontal convergence & TOPCON ES-101 total station & Accuracy: $1 \mathrm{~mm}$ & $\begin{array}{c}3-15 \text { days } \\
16 \text { days- } 1 \text { month } \\
\text { More than } 1 \\
\text { month }\end{array}$ & $\begin{array}{c}2-3 \text { times/day } \\
1 \text { time/day } \\
2-3 \text { times/ } \\
\text { week }\end{array}$ \\
\hline 2 & Crown settlement & TOPCON ES-101 total station & Accuracy: $1 \mathrm{~mm}$ & $\begin{array}{c}3-15 \text { days } \\
16 \text { days }-1 \text { month } \\
\text { More than } 1 \\
\text { month }\end{array}$ & $\begin{array}{c}2-3 \text { times/day } \\
1 \text { time/day } \\
2-3 \text { times/ } \\
\text { week }\end{array}$ \\
\hline 3 & Steel rib stress & $\begin{array}{l}\text { Steel string surface strain } \\
\text { gauge }\end{array}$ & $2000 \mu \varepsilon$ & \multicolumn{2}{|c|}{1 time/day } \\
\hline 4 & Shotcrete stress & Concrete strain gauge & $\mathrm{C} 25$ & \multicolumn{2}{|c|}{1 time/day } \\
\hline 5 & $\begin{array}{c}\text { Concrete stress in secondary } \\
\text { lining }\end{array}$ & Concrete strain gauge & $\mathrm{C} 30$ & \multicolumn{2}{|c|}{1 time/day } \\
\hline 6 & $\begin{array}{c}\text { Steel bar stress in secondary } \\
\text { lining }\end{array}$ & Steel bar stress meter & HRB400 & \multicolumn{2}{|c|}{1 time/day } \\
\hline
\end{tabular}

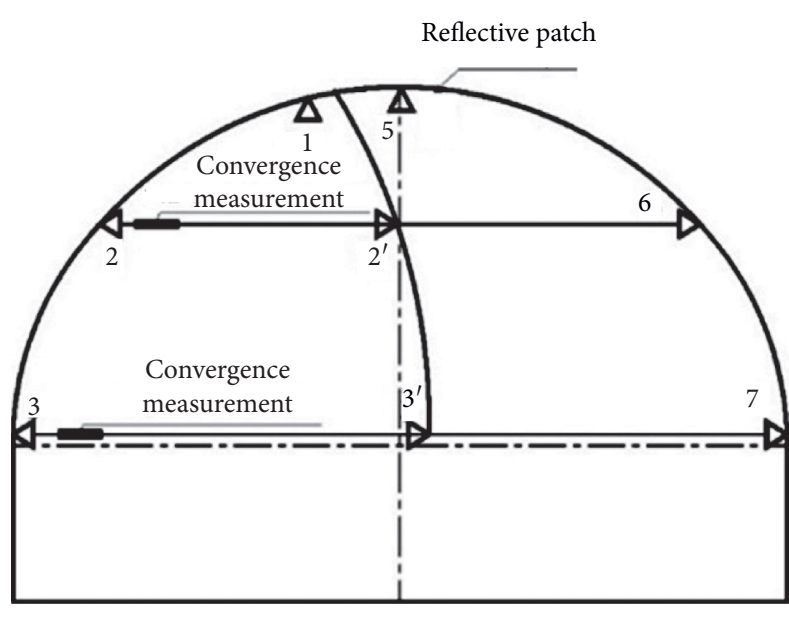

(a)

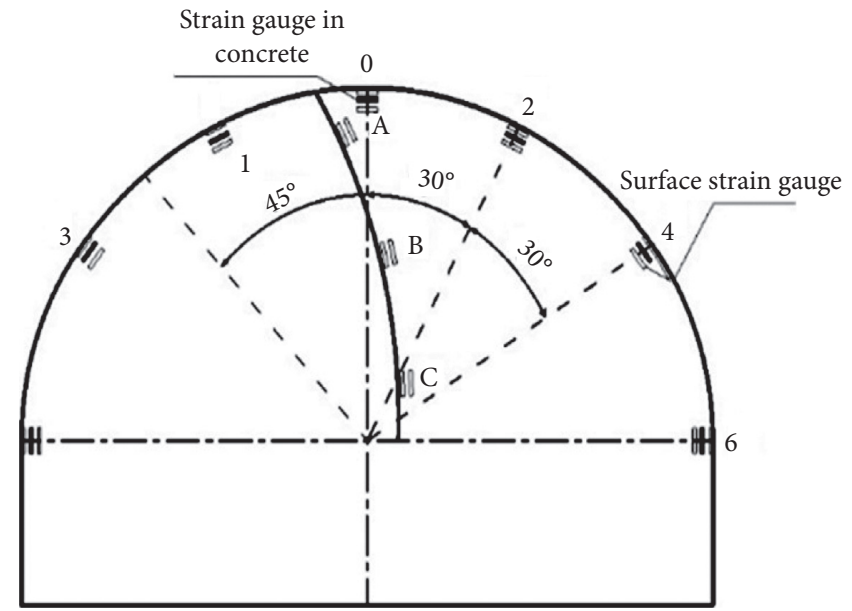

(b)

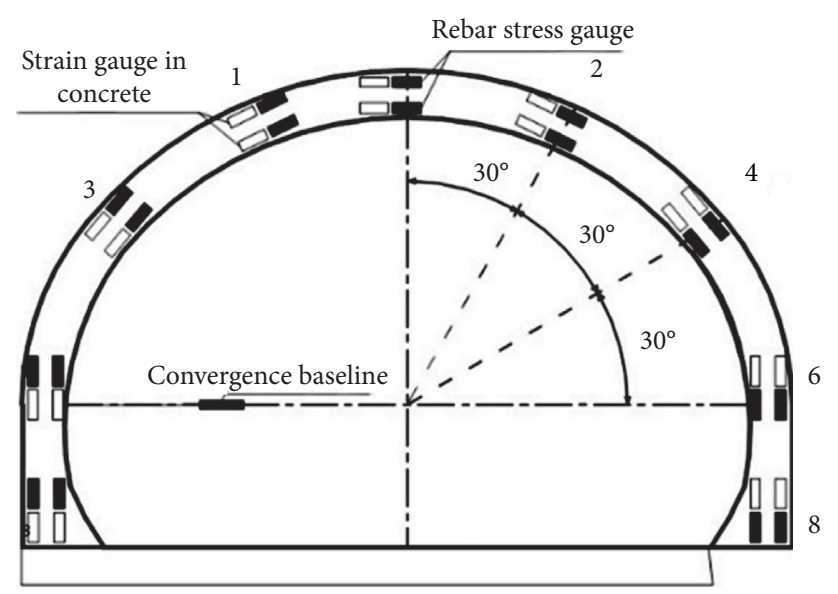

(c)

FIGURE 4: Layout of stress and deformation measuring points. (a) Layout of deformation monitoring points. (b) Stress monitoring points for primary support. (c) Stress monitoring points for secondary lining.

side. The maximum stress appeared at $60^{\circ}$ on the left side of haunch (point 3), which was $7.04 \mathrm{MPa}$, accounting for $56 \%$ of the axial compressive strength of C25 shotcrete (the axial compressive strength of C25 concrete was 11.9 $\mathrm{MPa}$ ). After the structure was stabilized, the maximum stress accounted for $54 \%$ of the C25 shotcrete axial compressive 
TABle 4: Deformation monitoring results.

\begin{tabular}{lcccc}
\hline $\begin{array}{l}\text { Mileage } \\
\text { number }\end{array}$ & $\begin{array}{c}\text { Maximum convergent } \\
\text { value }(\mathrm{mm})\end{array}$ & $\begin{array}{c}\text { The ratio of maximum convergent } \\
\text { to permissible value }(\%)\end{array}$ & $\begin{array}{c}\text { Maximum settlement } \\
\text { value }(\mathrm{mm})\end{array}$ & $\begin{array}{c}\text { The ratio of maximum settlement } \\
\text { to permissible value }(\%)\end{array}$ \\
\hline YK2 +444 & 14.7 & 11 & 21.2 & 15 \\
YK2 +449 & 8.8 & 6 & 14.8 & 11 \\
YK2 +453 & 11.3 & 8 & 13.6 & 10 \\
\hline
\end{tabular}
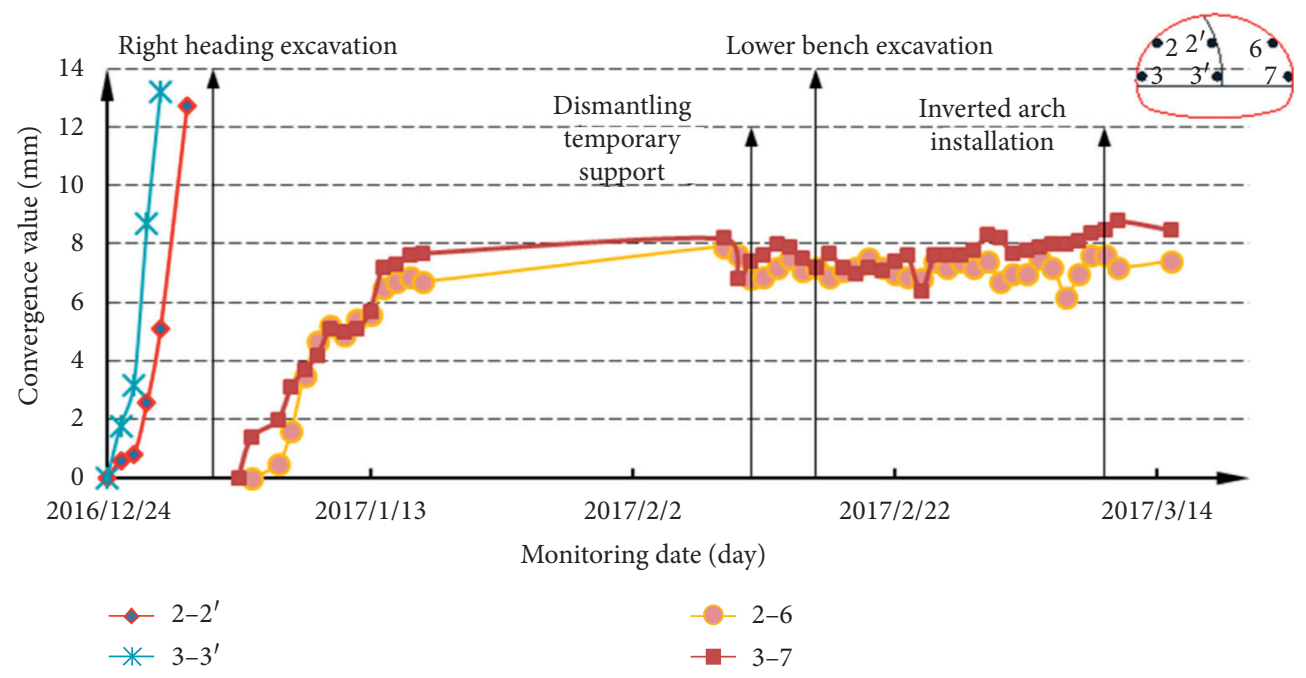

Figure 5: Horizontal convergence temporal curve at section YK2 +449 .

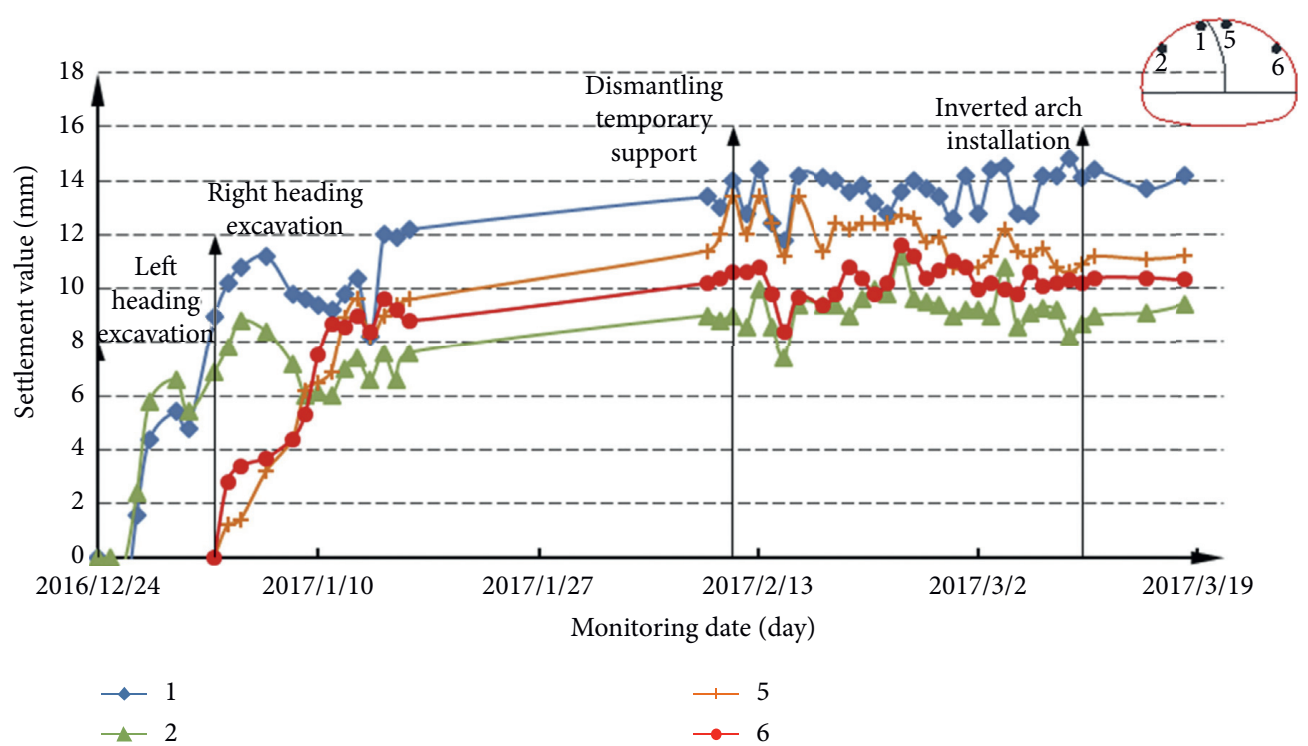

FIgURE 6: The temporal curve of the settlement of the crown at section YK2 +449.

strength. After the completion of primary support construction, the stress increased rapidly. The stress of shotcrete tended to be stable about 10 days after the pouring of inverted arch. Because of the hydration heat in the concrete consolidation process, the construction of secondary lining caused small fluctuation of shotcrete stress, and other construction procedures had less influence on the concrete stress of the support structure. About 20 days after the secondary lining was constructed, the concrete stress tended to be stable.
3.2.2. Steel Rib Stress. Figure 9 shows the maximum stress distribution of steel rib. The stress temporal curve of steel rib is shown in Figures 10-12.

Figure 9 shows that the stress distribution of steel rib at section YK2 + 449 was uneven, and final stable value was consistent with the maximum stress distribution. The steel rib was mainly subjected to compressive stress. The arch force of steel rib was slightly larger than that of the side wall. The outside stress of steel rib was slightly larger than that of 


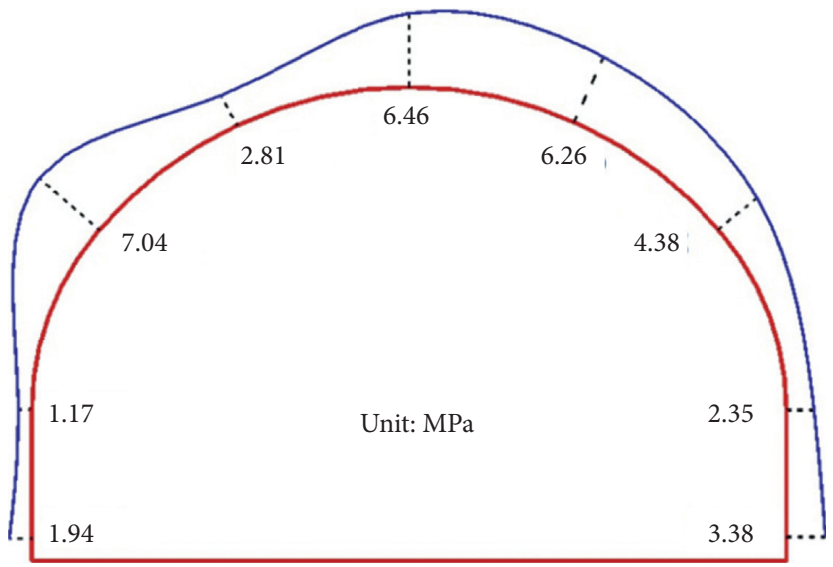

FIGURE 7: Stress distribution of shotcrete at section YK2 +449.

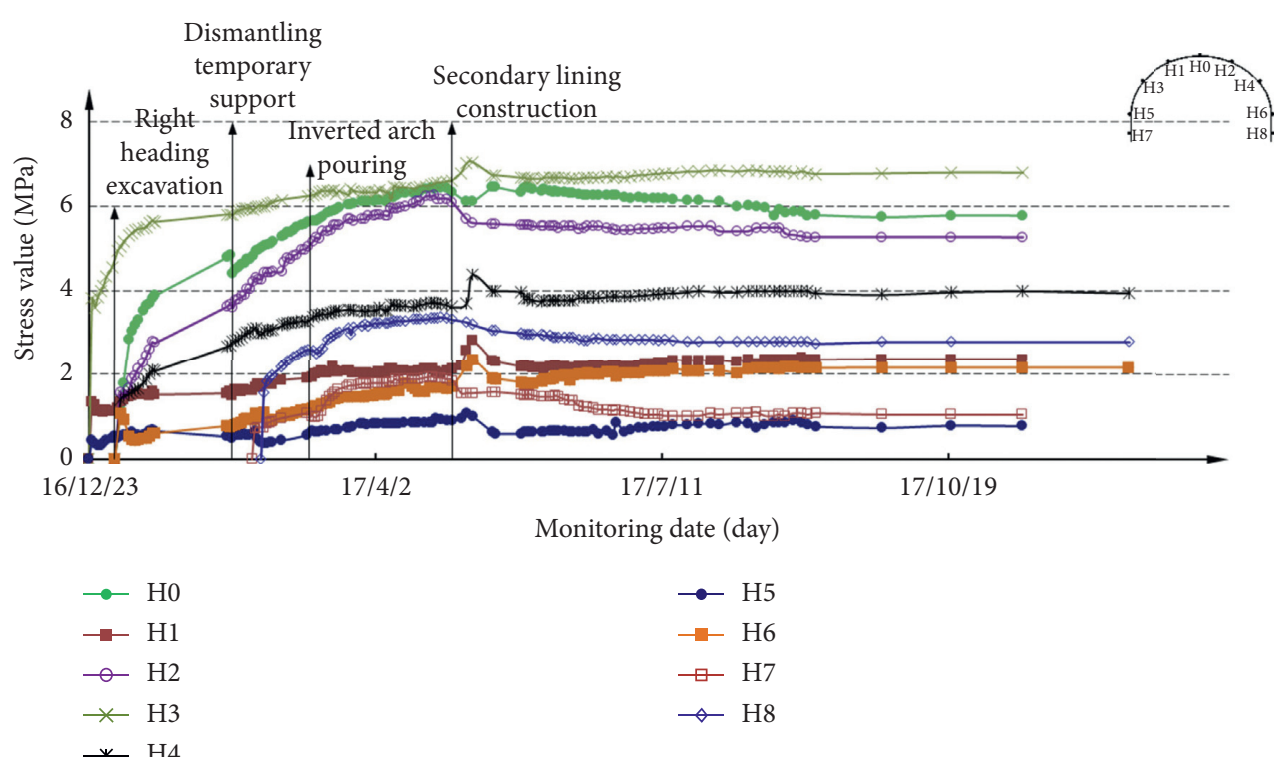

FIgURE 8: Stress temporal curve of shotcrete at section YK2 +449.

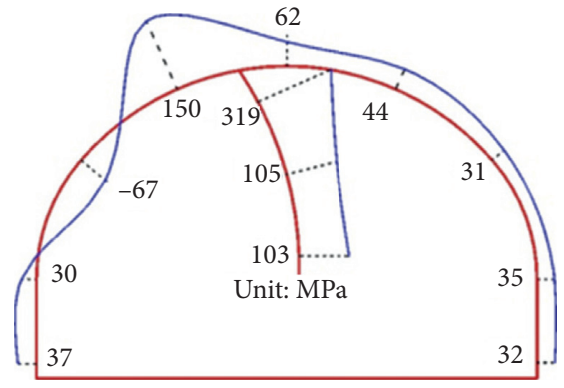

(a)

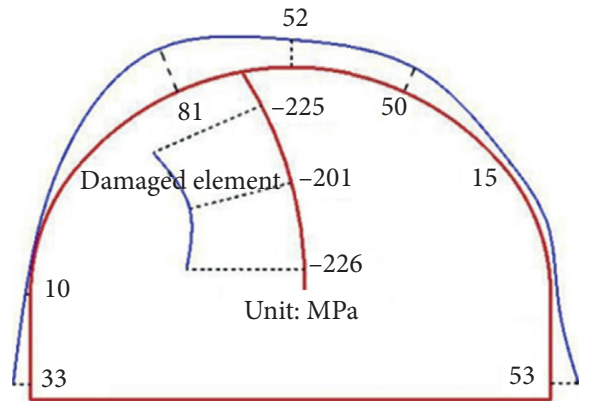

(b)

FIgURE 9: Stress distribution of steel rib at YK2 +449 section. (a) Maximum stress outside the steel rib. (b) Maximum stress inside the steel rib.

the inside. The maximum compressive stress of steel rib (outside) occurred at the right side of haunch (point 1), which was $150 \mathrm{MPa}$, accounting for $40 \%$ of the ultimate yield strength of steel. The maximum compressive stress of inside at the steel rib appeared at the haunch (point 1), which was $81 \mathrm{MPa}$, accounting for $22 \%$ of the ultimate yield strength of steel. As shown in Figures 9-12, the force of steel rib was small, so the primary support structure was safe and reliable. The 


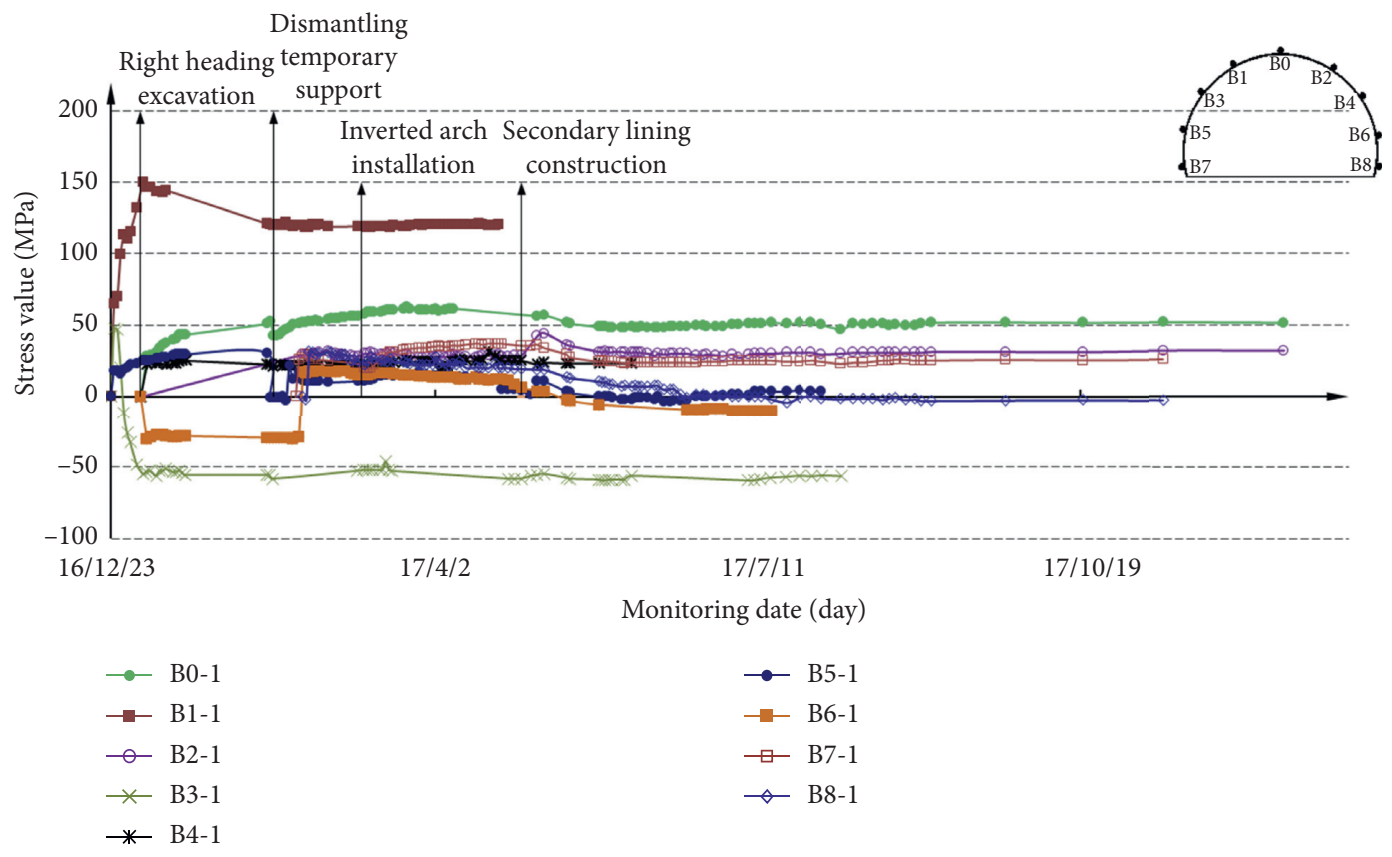

Figure 10: Stress temporal curves at the outside of steel rib at section YK2 +449 .

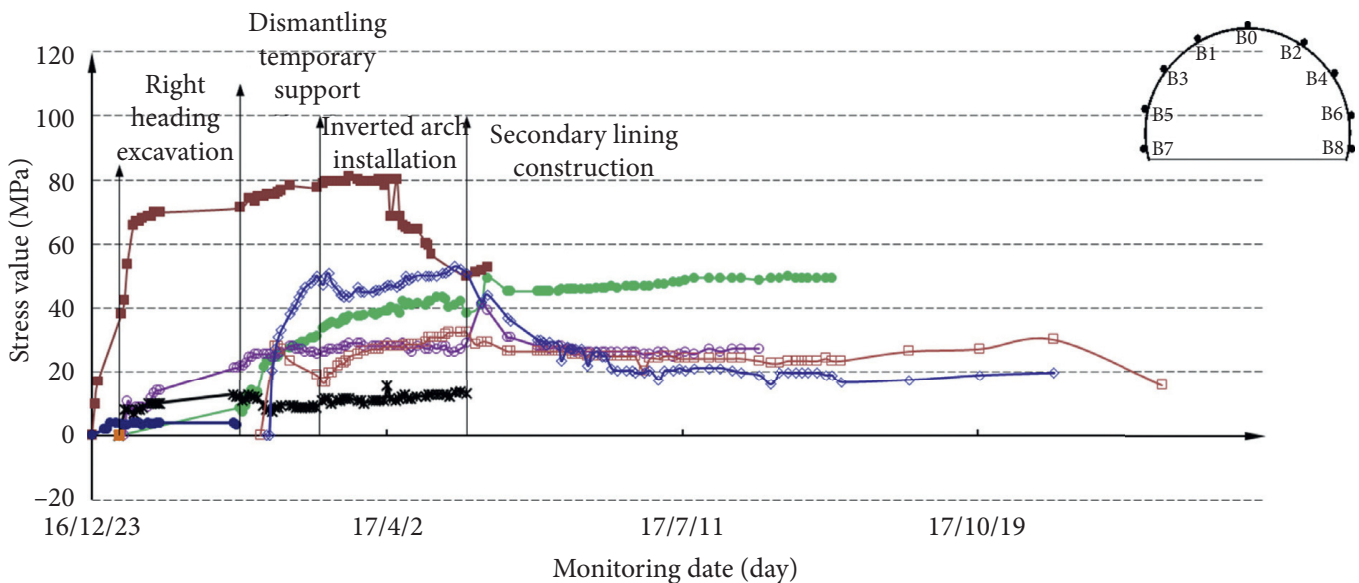

$\rightarrow \mathrm{B} 0-2$
$-\mathrm{B} 1-2$
$-\mathrm{B} 2-2$
$* \mathrm{~B} 3-2$
$* \mathrm{~B} 4-2$

$\rightarrow$ B5-2
$\rightarrow$ B6-2
$\square$ B7-2
$\multimap$ B8-2

Figure 11: Stress temporal curves at the inside of steel rib at section YK2 +449 .

outside of temporary support was mainly compressed, and the inner side was mainly tensioned. The maximum compressive stress appeared in the arch (A), which was $319 \mathrm{MPa}$, accounting for $85 \%$ of the ultimate yield strength of steel. The maximum tensile stress appeared at the skewback (C), which was $226 \mathrm{MPa}$, accounting for $60 \%$ of the ultimate yield strength of steel. The overall force of the temporary support was large. After the right drift was excavated, the stress of steel rib changed suddenly due to the blasting vibration. From the actual situation of project site, the temporary support steel rib exhibited yielding phenomenon; moreover, local concrete spalled. With right pilot tunnel excavation, the stress of steel ribs did not change significantly, which indicated that the steel rib structure was safe and could meet the structural safety requirements. After the primary support was applied, the stress of steel rib increased rapidly in the early stage and tended to be stable after about 7 days. Compared with other processes, the stress of steel rib at arch changed more obviously when the temporary support was removed. About 20 days after the completion of secondary lining, the primary support tended to be stable. 


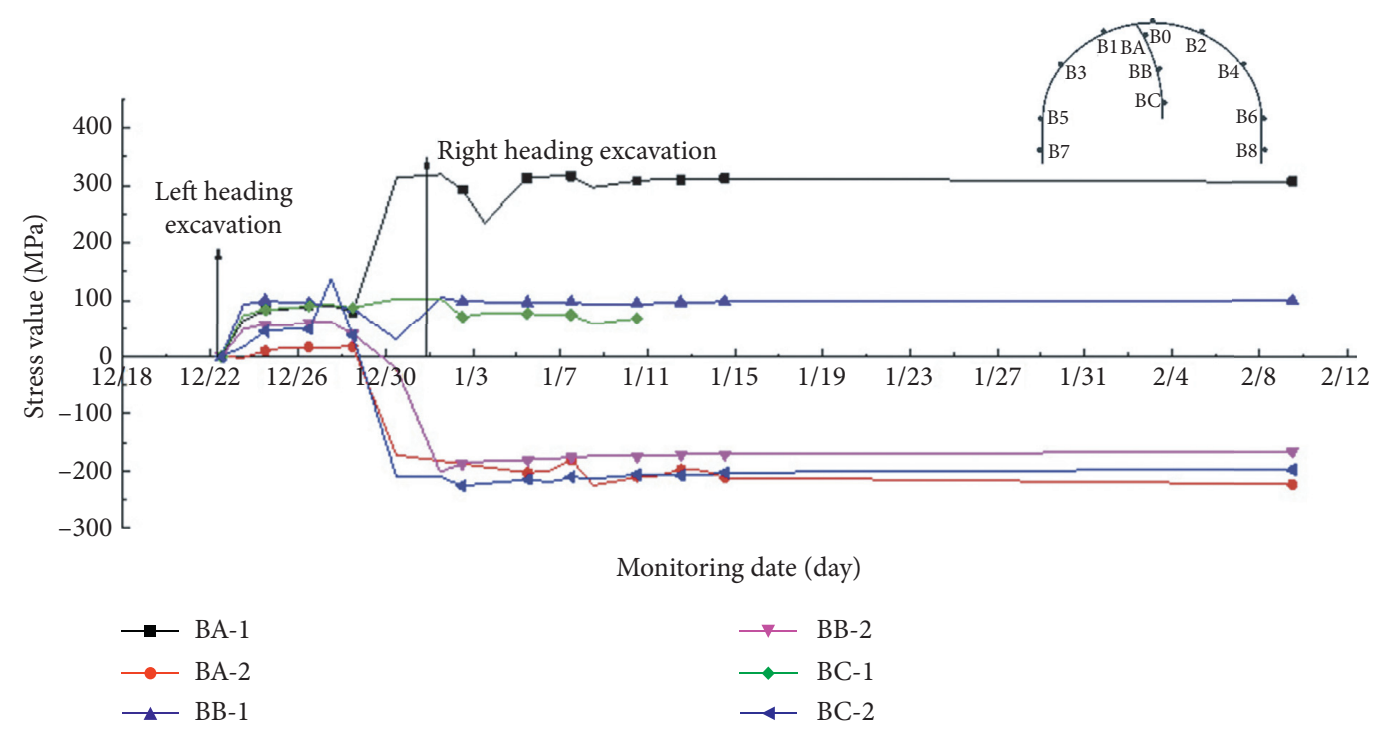

Figure 12: Stress temporal curves at the middle wall of steel rib at section YK2 +449 .

3.2.3. Stress of Steel Bar in Secondary Lining. The stress distribution of the steel bar in secondary lining is shown in Figure 13. The temporal curves of the secondary lining steel bar stress are shown in Figures 14 and 15.

As shown in Figures 13(a) and 14, the maximum compressive stress of outer side steel bar in secondary lining occurred at $30^{\circ}$ on the left side of hance (point 1), which was $32 \mathrm{MPa}$, accounting for only $8 \%$ of the yield strength of the steel bar. As shown in Figures 13(b) and 15, the maximum compressive stress occurred at the left skewback (point 5), which was $39 \mathrm{MPa}$, accounting for $10 \%$ of the yield strength of steel bar. The maximum tensile stress appeared at the vault (point 0 ), which was $7 \mathrm{MPa}$, accounting for $2 \%$ of the yield strength of steel bar.

Figures 14 and 15 show that the secondary lining steel bars at section $\mathrm{YK} 2+449$ were mainly in the compressive state. The change rule of the stress in two sides of secondary lining was consistent. After the construction of secondary lining was completed, the stress of steel bar increased slowly, and it tended to be stable after about 30 days, which indicated that the steel bars in secondary lining worked well and had sufficient surplus strength.

3.2.4. Secondary Lining Concrete Stress. Figure 16(a) indicates that the maximum tensile stress on the outer side of the secondary lining concrete occurred at the left skewback (point 5 ), and its value was $0.87 \mathrm{MPa}$, which was less than the standard tensile value of C30 concrete $(2.01 \mathrm{MPa})$. The maximum compressive stress occurred at the left hance (point 1), and the value was $2.04 \mathrm{MPa}$, which was only $10 \%$ of the standard value of C30 concrete compressive strength. It could be seen from Figure 16(b) that the maximum tensile stress on the inner side of the secondary lining concrete appeared at the vault (point 0 ), and its value was $0.87 \mathrm{MPa}$, which was less than the standard tensile value of $\mathrm{C} 30$ concrete $(2.01 \mathrm{MPa})$. The maximum compressive stress occurred at the left hance (point 4), and its value was $2.02 \mathrm{MPa}$. It can be seen from Figures 17 and18 that the stress distribution of the inner and outer stress of secondary lining concrete was basically similar, and the overall structure was mainly in compression. Only the vault and the skewback were in the tension state. The stress of right side of secondary lining concrete was slightly larger than that of the left. The internal and external stresses of secondary lining concrete had the same trend with time. After inverted arch filling, the pressure of the concrete at the side wall increased gradually under the action of self-weight and other loads. After the secondary lining reached ring closure, the concrete pressure at the side wall (point 8) was almost unchanged, and the rest increased slowly. The concrete stress of secondary lining tended to be stable after 25 days. In general, the stress of structure was small, and the structure was safe and reliable.

Generally speaking, the stress state of tunnel support structure is mainly affected by the construction process and change of support structure constraints. With the gradual construction of each excavation part in the tunnel, the overall stress of the inner and outer sides of primary support and secondary lining increases sharply at first and then tends to be stable gradually. At the same time, except for the upper outer side of middle diaphragm steel rib, the stress of each measuring point at the support structure steel rib is less than the yield limit of steel frame $(235 \mathrm{MPa})$, and the support structure is safe and stable in the process of tunnel construction. The internal and external stress of steel rib and the shotcrete stress increased rapidly after the left heading pilot excavation, then continued to change with the excavation of right heading pilot, especially the steel rib stress at the middle diaphragm, and the stress tended to be stable after the secondary lining construction finally, which indicated that the safety and stability of tunnel support structure is closely related to the construction process and the change of constraint conditions for the support structure.

\section{Optimization Study of Support Parameters}

The stress state of primary support is an important basis to evaluate the safety and stability of tunnel structure. The load- 


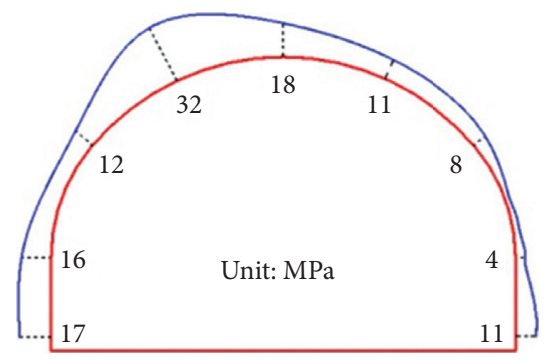

(a)

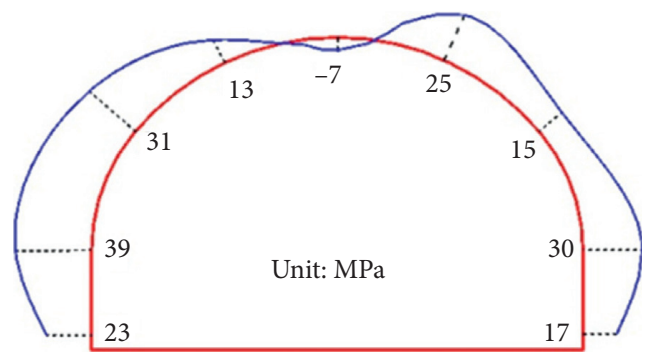

(b)

FIGURE 13: Stress distribution of secondary lining steel bar at YK2 + 449 section. (a) Maximum stress of outer side steel bar $i$ (b) Maximum stress of inner side steel bar.

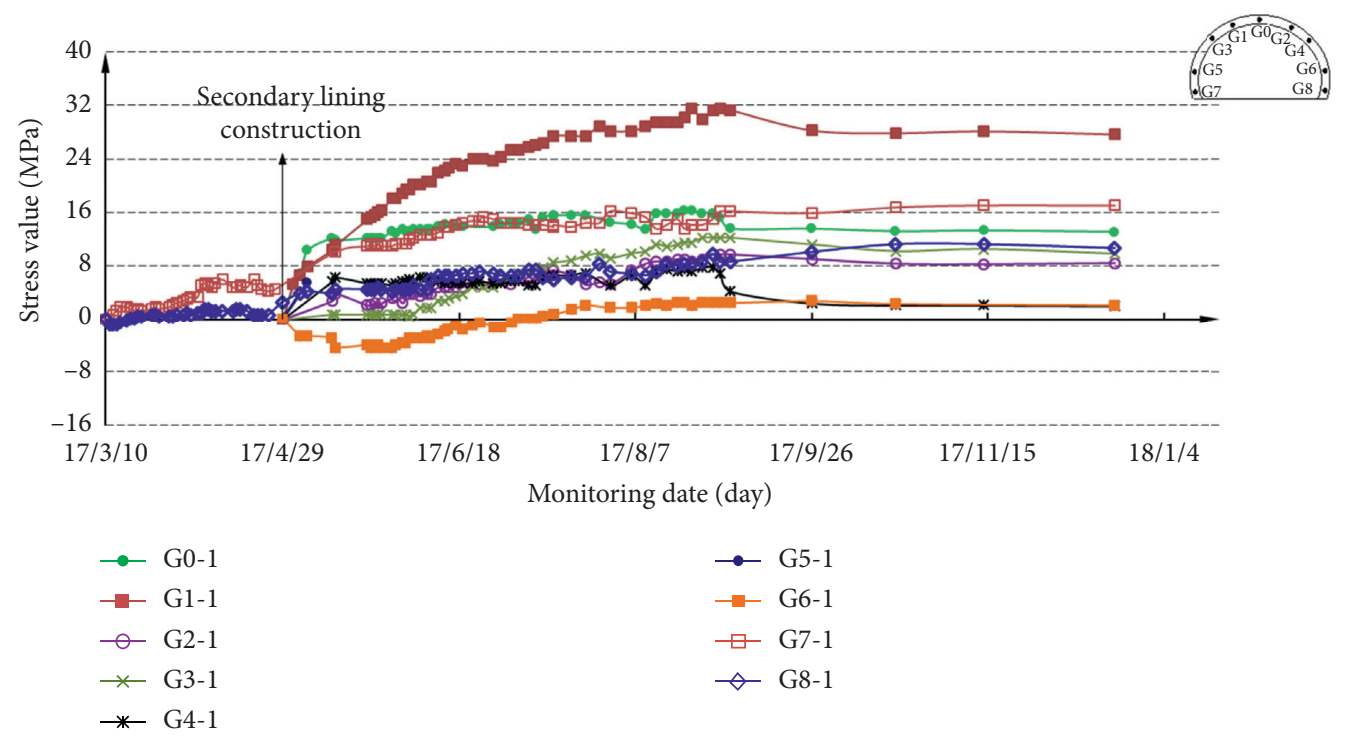

Figure 14: Stress temporal curves of outer side steel bar in secondary lining at section YK2 + 449 .

structure method has the advantages of clear calculation procedures, intuitive rock mass load, and wide engineering application. According to the measured force and deformation results in the section $\mathrm{YK} 2+449$ of Laohushan Tunnel, based on the load-structure method [39-41], MIDAS-GTS was used for numerical simulation [33]. The safety of primary support structure under different support parameters is simulated and calculated, and the reasonable support parameters of Laohushan highway tunnel are studied considering the structural safety and engineering economy. The detailed calculation process is shown in Figure 19. It was assumed that the rock mass is an elastoplastic material and the primary support was an elastic material. The physical parameters of steel rib and shotcrete were equivalently reduced according to The Unified Theory of Concrete Filled Steel Tube, and the mechanical parameters after the equivalent reduction were used as the modeling parameters of primary support. In this paper, the comprehensive safety factor method in the Specifications for Design of Highway Tunnels (JTG/TD70 - 2018) [8] was used to check and evaluate the primary support of Laohushan Tunnel. When calculating the axial force, bending moment of steel rib and shotcrete, the total axial force, and the total bending moment assumed by the primary support were distributed to the steel rib and the shotcrete according to equations (1)-(4).

$$
\begin{aligned}
& N_{h}=N \frac{A_{h} E_{h}}{A_{h} E_{h}+A_{g} E_{g}}, \\
& M_{h}=0, \\
& N_{g}=N \frac{A_{g} E_{g}}{A_{h} E_{h}+A_{g} E_{g}}, \\
& M_{g}=M,
\end{aligned}
$$

where $N_{h}$ is the axial force assumed by shotcrete $(\mathrm{kN}) ; N$ is the total axial force of cross section in the unit length $(\mathrm{kN})$; $A_{h}$ is the shotcrete area; $E_{h}$ is the elastic modulus of shotcrete $(\mathrm{kPa}) ; A_{g}$ is the calculated section area of a steel $\mathrm{rib}\left(\mathrm{m}^{2}\right) ; E_{g}$ is the Elastic modulus of steel rib $(\mathrm{kPa}) ; M_{h}$ is the bending moment of shotcrete $(\mathrm{kN} \cdot \mathrm{m}) ; N_{g}$ is the axial force assumed by the steel rib $(\mathrm{kN}) ; M_{g}$ is the bending moment of a steel rib 


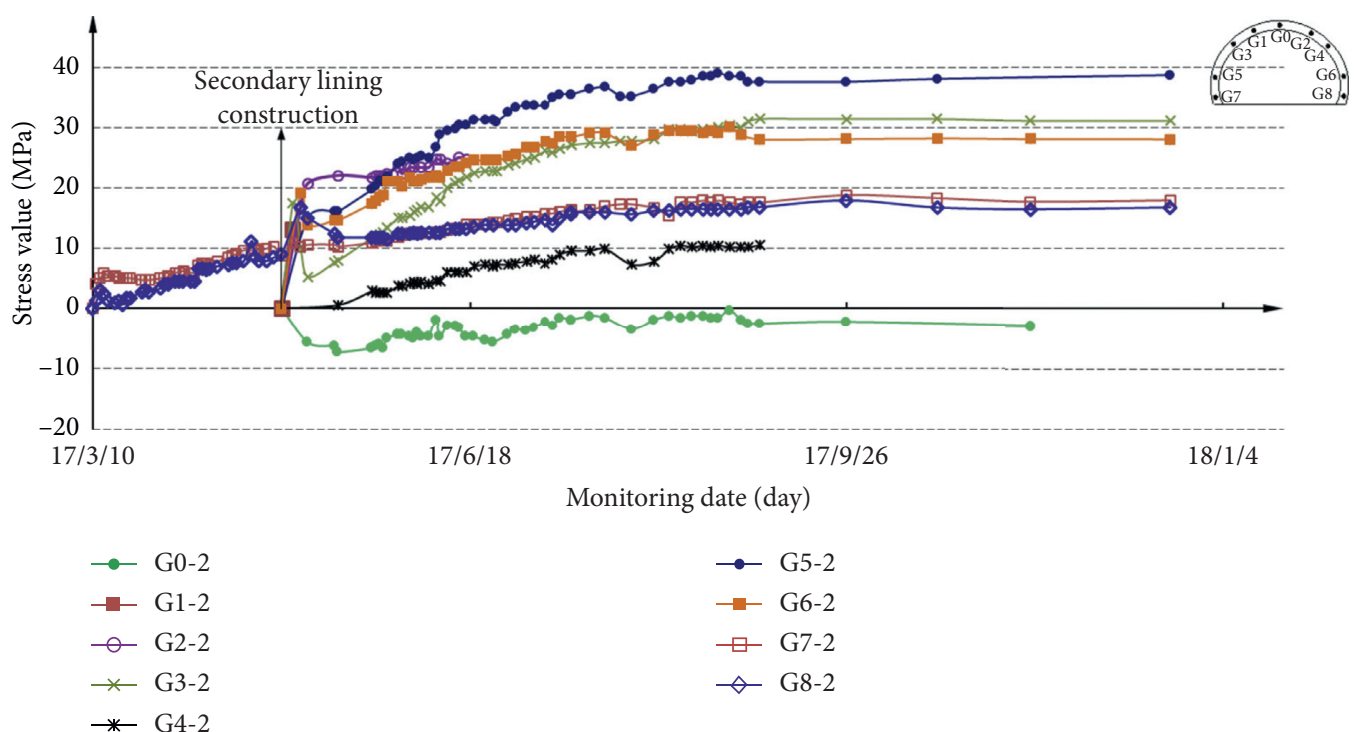

FIGURE 15: Stress temporal curves of inner side steel bar in secondary lining at section YK2 +449 .

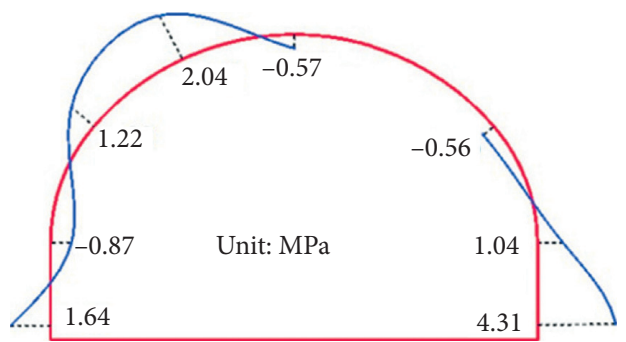

(a)

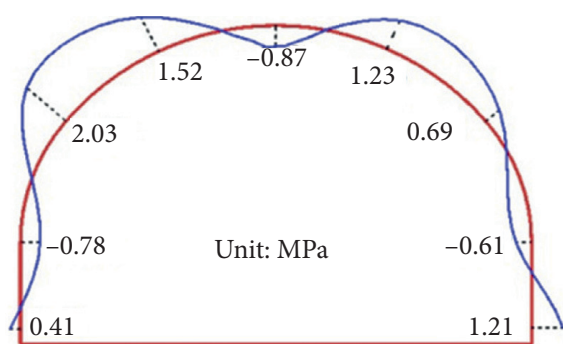

(b)

FIgURE 16: Stress distribution of secondary lining concrete at section YK2 + 449. (a) Stress maximum of outer side of concrete. (b) Stress maximum of inner side of concrete.

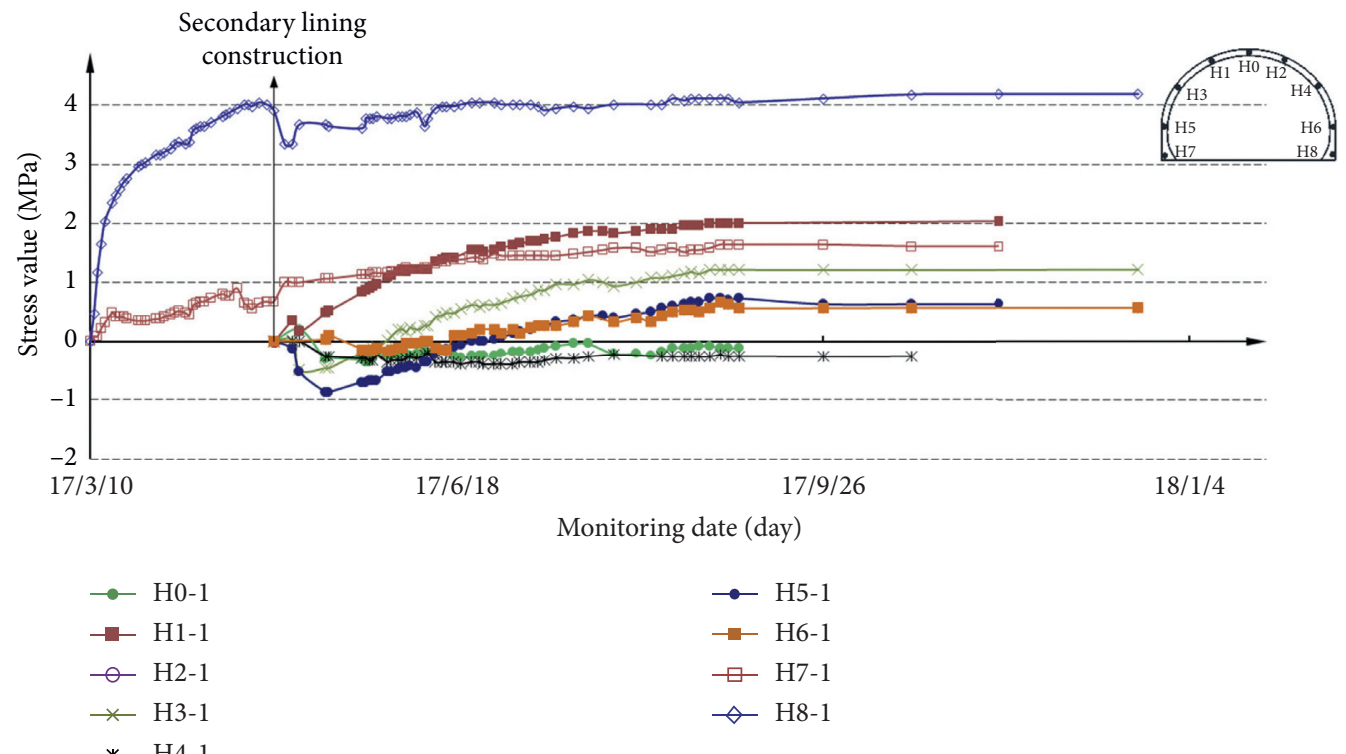

FiguRE 17: Lateral temporal curve of secondary lining concrete at section YK2 +449 . 
( $\mathrm{kN} \cdot \mathrm{m})$; and $M$ is the total bending moment of cross section in the unit length $(\mathrm{kN} \cdot \mathrm{m})$.

When the strength of shotcrete and steel rib is checked by comprehensive safety factor method, its strength should conform to equations (5)-(7). The formula is as follows:

$$
\begin{aligned}
K_{h y} N_{h} & \leq \alpha R_{h y} A_{h}, \\
K_{g}\left(\frac{N_{g}}{A_{g}}+\frac{M_{g}}{W_{g}}\right) & \leq R_{g y}, \\
K_{g}\left(\frac{N_{g}}{A_{g}}-\frac{M_{g}}{W_{g}}\right) & \leq R_{g l},
\end{aligned}
$$

where $K_{h y}$ is the compressive safety factor of compressive strength of shotcrete $(\mathrm{kPa}) ; \alpha$ is the eccentric influence coefficient; $R_{h y}$ is the compressive ultimate strength of shotcrete $(\mathrm{kPa}) ; K_{g}$ is the compressive safety factor of compressive and the tensile strength of steel rib $(\mathrm{kPa}) ; W_{g}$ is the steel rib checking calculation of cross section bending strength $\left(\mathrm{m}^{3}\right) ; R_{g y}$ is the compressive ultimate strength of steel rib ( $\mathrm{kPa})$; and $R_{g l}$ is the ultimate tensile strength of steel rib $(\mathrm{kPa})$.

The physical and mechanical parameters of the rock mass used in the modeling are shown in Table 5. The model diagram is shown in Figure 20.

4.1. Analysis of Tunnel Support Parameters. The simulation results of YK2 +449 section are shown in Figure 21 . According to the numerical simulation results, 9 monitoring points were selected in the primary support of the model for the analysis of structural force and safety factors, and the arrangement of monitoring points was consistent with that of on-site monitoring points. The structure was calculated according to the calculation method of internal force and safety factor in Specifications for Design of Highway Tunnels (2018) [8]. The calculation results are shown in Table 6.

Table 6 shows that the structural stress in the primary support model is basically consistent with the in situ test results. For the primary support, the stress at arch was slightly larger than that of the side wall. The maximum axial force of shotcrete occurred at $60^{\circ}$ on the left side of the hance, with a value of $1787 \mathrm{kN}$ and a safety factor of 2.6 . The maximum bending moment of the steel rib appeared at the right skewback with a value of $-12 \mathrm{kN} \cdot \mathrm{m}$ and a safety factor of 3.1. According to the "Specifications for Design of Highway Tunnels" (2010) [8], the safety factors of steel rib and shotcrete under the basic variable combination of II are 2.0 (steel bar ultimate strength) and 2.4 (shotcrete ultimate strength of compression). The safety factor of the primary support structure at section YK2 + 449 was larger than the specified value, indicating that the design parameters could meet the structural safety. The in situ monitoring result also indicated that the stress of secondary lining was small, and the secondary lining could be used as a safety reserve. Therefore, the primary support parameters could be optimized.
4.2. Optimization of Tunnel Support Parameters. In view of the actual design schemes and the stress characteristics of the primary support of Laohushan Tunnel section in Grade IV rock mass, three schemes were proposed, and then the optimal scheme was selected by contrast. The primary support parameter optimization scheme and material physical parameters are shown in Table 7.

4.2.1. Parameter 1. In option 1, I25b steel rib was used, with a distance of $80 \mathrm{~cm}$, and the other parameters remained unchanged. The stress of primary support structure was obtained through numerical calculation and theoretical calculation, and the results were shown in Table 8 .

Table 8 shows that the axial force of the shotcrete at $60^{\circ}$ on the left side of the primary support was the largest, with the value of $1859 \mathrm{kN}$ and safety factor of 2.9. At the same time, the safety factor of shotcrete at this point is the smallest, but it was greater than the compressive safety factor of shotcrete specified by the Specifications for Design of Highway Tunnels [8], which indicated that the shotcrete under this scheme could satisfy the structural safety. The steel rib at the vault had the largest bending moment and its value was $-7.4 \mathrm{kN} \cdot \mathrm{m}$. The corresponding compression safety factor was 2.0, which met the requirements of rules and the safety requirements of steel ribs. It can be considered that the scheme was feasible.

4.2.2. Parameter 2. Option 2 adopted $\mathrm{H} 175 \times 175$ steel rib with a distance of $80 \mathrm{~cm}$ and C25 shotcrete with a thickness of $26 \mathrm{~cm}$. The other parameters remained unchanged. The stress of primary support structure was obtained through numerical calculation and theoretical calculation, and the results are shown in Table 9.

Table 9 shows that the maximum axial force of the shotcrete occurred at $60^{\circ}$ on the left side of the hance, which was $1837 \mathrm{kN}$. The safety factor was 2.6 , which was greater than the compressive safety factor (2.4) according to Specifications for Design of Highway Tunnels (2018) [8], which indicated that the shotcrete under parameter 2 satisfied the safety requirements. The maximum bending moment of steel rib appeared at the vault, and its value was $-7.6 \mathrm{kN} \cdot \mathrm{m}$. The corresponding safety factor was the minimum safety factor of 3.7, which was larger than the safety factor of the steel rib in the code. Therefore, parameter 2 can be considered feasible.

4.2.3. Parameter 3. For parameter 3, I22b steel rib was used with a distance of $75 \mathrm{~cm}$. The other parameters remained unchanged. The stress of primary support structure was obtained through numerical calculation and theoretical calculation, and the results are shown in Table 10 .

Table 10 shows that the maximum stress of the shotcrete occurred at left hance, which was $1845 \mathrm{kN}$. The safety factor was 2.7, which was larger than the compressive safety factor in Specifications for Design of Highway Tunnels (2018) [8], which indicated that the shotcrete could meet the structural safety under parameter 3 . The maximum bending moment 


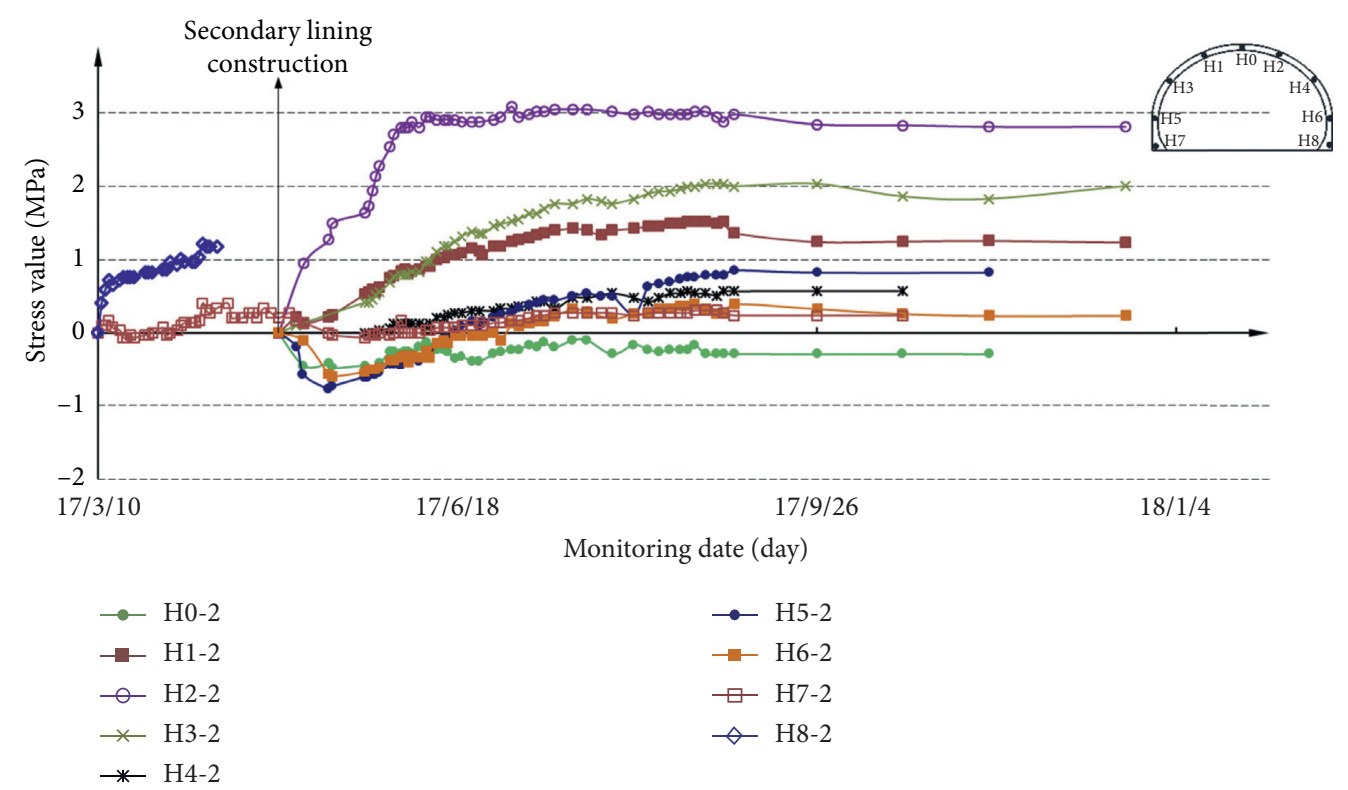

FIGURE 18: Inner temporal curve of secondary lining concrete at section YK2 +449.

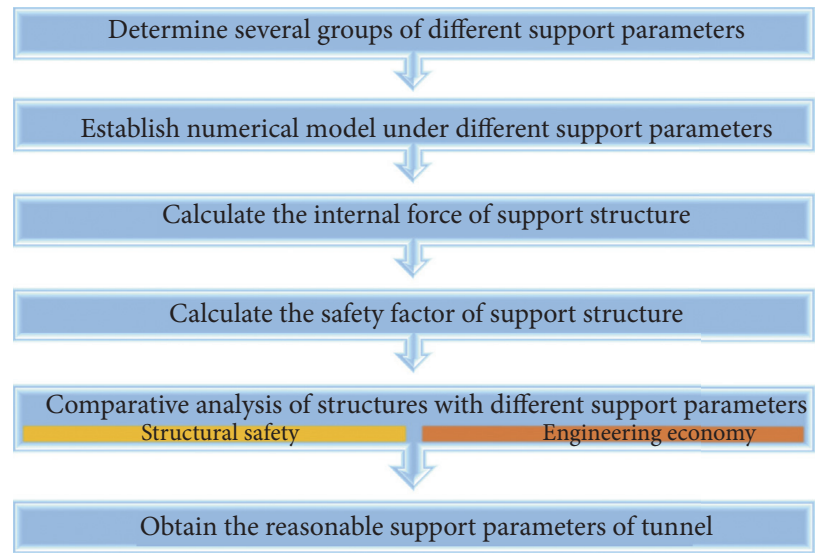

Figure 19: Calculation process for reasonable support parameters.

TABLE 5: Physical and mechanical parameters of surrounding rock.

\begin{tabular}{lllll}
\hline Rock mass Deformation modulus E (GPa) Poisson ratio $\mu$ Internal friction angle $f\left({ }^{\circ}\right)$ Cohesion C $(\mathrm{MPa}) \quad$ Rock mass gravity $\left(\mathrm{kN} / \mathrm{m}^{3}\right)$ \\
\hline
\end{tabular}

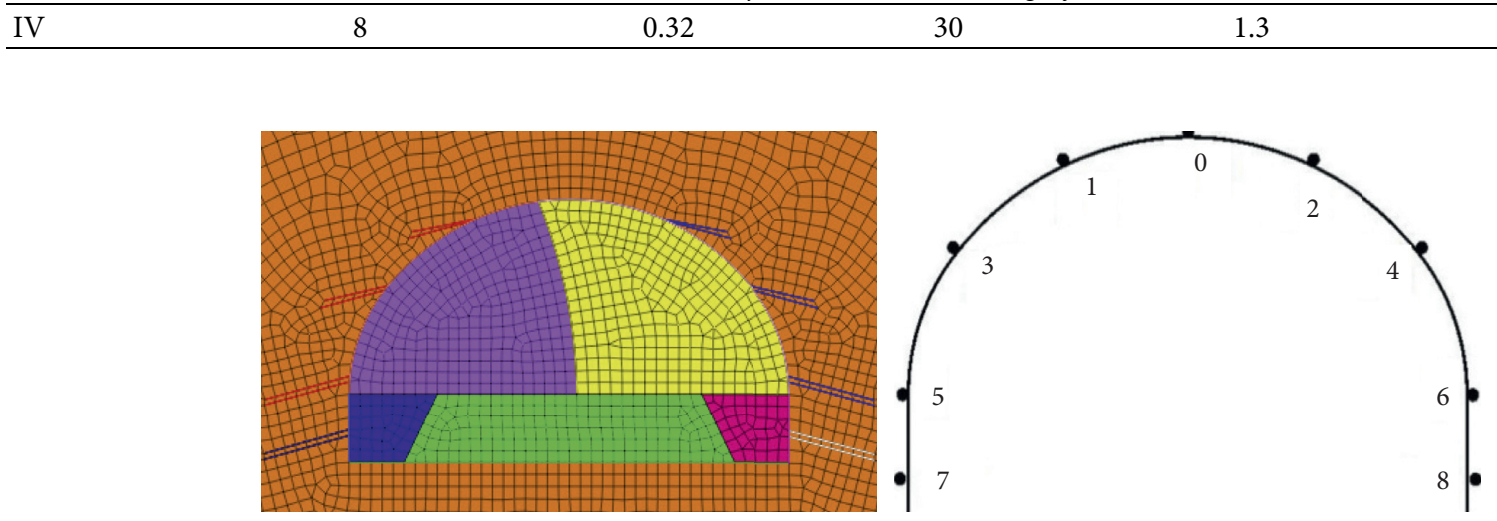

Figure 20: YK2 + 449 section model. 


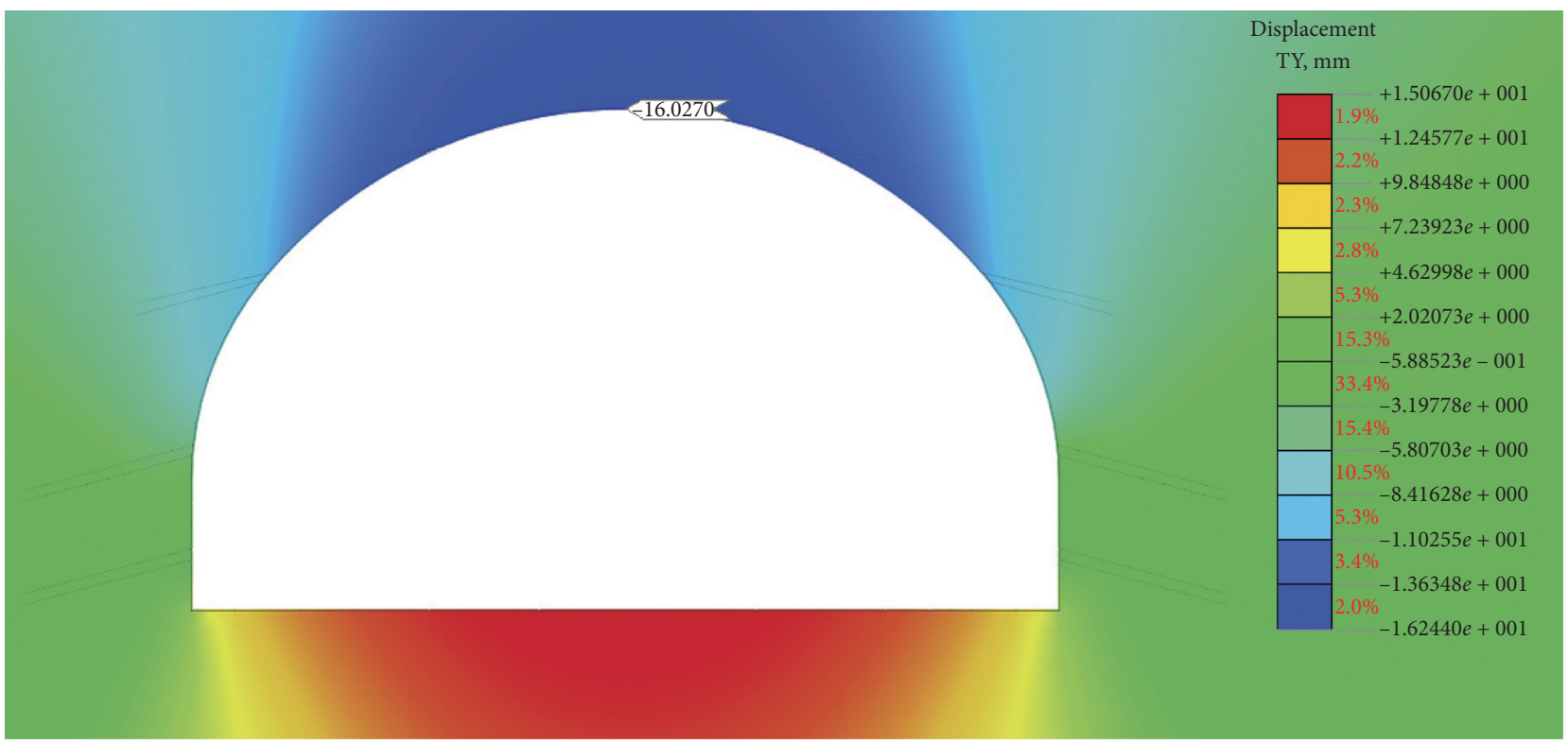

(a)

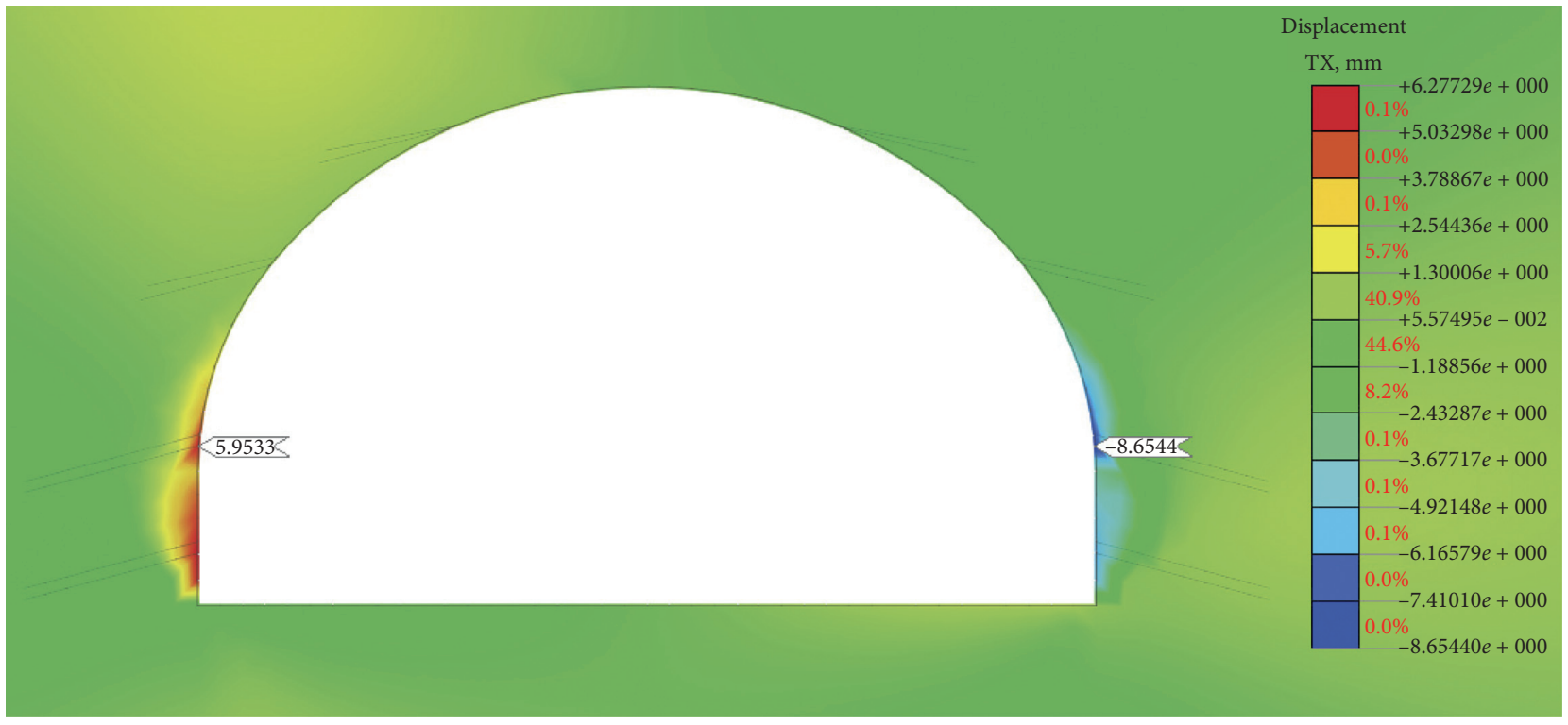

(b)

FIgURe 21: Deformation nephogram of YK2 + 449 section. (a) Crown settlement. (b) Horizontal convergence.

Table 6: Primary support internal force and material safety factor.

\begin{tabular}{|c|c|c|c|c|c|c|c|}
\hline Number & Position & $\begin{array}{c}\text { Shotcrete axial } \\
\text { force }(\mathrm{kN})\end{array}$ & $\begin{array}{l}\text { Axial force of } \\
\text { steel rib }(\mathrm{kN})\end{array}$ & $\begin{array}{l}\text { Steel rib bending } \\
\text { moment }(\mathrm{kN} \cdot \mathrm{m})\end{array}$ & $\begin{array}{c}\text { Shotcrete } \\
\text { safety factor }\end{array}$ & $\begin{array}{c}\text { Steel rib tensile } \\
\text { safety factor }\end{array}$ & $\begin{array}{c}\text { Steel rib compression } \\
\text { safety factor }\end{array}$ \\
\hline 0 & Vault & 506.9 & 141.7 & -7.9 & 8.3 & 12.3 & 4.7 \\
\hline 1 & $\begin{array}{c}\text { Vault deviated } \\
\text { left } 30^{\circ}\end{array}$ & 1421.0 & 397.1 & -4.2 & 3.2 & & 3.8 \\
\hline 2 & $\begin{array}{l}\text { Vault deviated } \\
\text { right } 30^{\circ}\end{array}$ & 829.6 & 231.9 & -2.2 & 5.2 & & 6.8 \\
\hline 3 & Left hance $60^{\circ}$ & 1787.5 & 499.6 & -1.2 & 2.6 & 4.8 & 3.9 \\
\hline 4 & $\begin{array}{c}\text { Right hance } \\
60^{\circ}\end{array}$ & 1042.7 & 291.4 & -8.0 & 4.2 & 74.7 & 3.5 \\
\hline 5 & Left skewback & 1304.4 & 364.6 & -3.3 & 3.5 & & 4.3 \\
\hline 6 & $\begin{array}{c}\text { Right } \\
\text { skewback }\end{array}$ & 760.4 & 212.5 & -12.0 & 5.6 & 8.0 & 3.1 \\
\hline 7 & Left side wall & 183.7 & 51.3 & 5.4 & 22.1 & 12.9 & 8.0 \\
\hline 8 & Right side wall & 15.6 & 4.4 & -0.1 & 256.6 & & 275.8 \\
\hline
\end{tabular}


TABLE 7: Optimized parameters of primary support.

\begin{tabular}{|c|c|c|c|c|c|c|}
\hline \multirow{2}{*}{ Parameter } & \multirow{2}{*}{ Steel rib model } & \multirow{2}{*}{ Steel rib spacing $(\mathrm{cm})$} & \multirow{2}{*}{ Shotcrete thickness $(\mathrm{cm})$} & \multicolumn{3}{|c|}{$\begin{array}{c}\text { Primary support equivalent reduction material } \\
\text { parameters }\end{array}$} \\
\hline & & & & $\begin{array}{c}\text { Deformation } \\
\text { modulus E }(\mathrm{GPa})\end{array}$ & $\begin{array}{c}\text { Steel rib } \\
\text { gravity }\left(\mathrm{kN} / \mathrm{m}^{3}\right)\end{array}$ & $\begin{array}{l}\text { Poisson } \\
\text { ratio } \mu\end{array}$ \\
\hline 1 & $\mathrm{I} 25 \mathrm{~b}$ & 80 & 30 & 27.7 & 23.3 & 0.22 \\
\hline 2 & $\mathrm{H} 175 \times 175$ & 80 & 26 & 28.2 & 23.4 & 0.22 \\
\hline 3 & $\mathrm{I} 22 \mathrm{~b}$ & 75 & 28 & 27.6 & 23.2 & 0.22 \\
\hline
\end{tabular}

TABLE 8: Internal force and safety factor of primary support under parameter 1.

\begin{tabular}{|c|c|c|c|c|c|c|c|}
\hline $\begin{array}{l}\text { Monitoring } \\
\text { point }\end{array}$ & Position & $\begin{array}{l}\text { Shotcrete axial } \\
\text { force }(\mathrm{kN})\end{array}$ & $\begin{array}{l}\text { Axial force of } \\
\text { steel rib }(\mathrm{kN})\end{array}$ & $\begin{array}{l}\text { Steel rib bending } \\
\text { moment }(\mathrm{kN} \cdot \mathrm{m})\end{array}$ & $\begin{array}{l}\text { Shotcrete } \\
\text { safety factor }\end{array}$ & $\begin{array}{c}\text { Steel rib } \\
\text { tensile safety } \\
\text { factor }\end{array}$ & $\begin{array}{c}\text { Steel rib } \\
\text { compression safety } \\
\text { factor }\end{array}$ \\
\hline 0 & $\begin{array}{l}\text { Crown } \\
\text { Crown }\end{array}$ & 511.8 & 104.2 & -7.4 & 9.3 & 2.6 & 2.0 \\
\hline 1 & $\begin{array}{c}\text { deviated left } \\
30^{\circ} \\
\text { Crown }\end{array}$ & 1472.9 & 299.8 & -3.9 & 3.5 & 16.4 & 2.5 \\
\hline 2 & $\begin{array}{c}\text { deviated right } \\
30^{\circ}\end{array}$ & 857.3 & 174.5 & -2.2 & 5.7 & 32.9 & 4.4 \\
\hline 3 & $\begin{array}{l}\text { Left haunch } \\
\qquad 60^{\circ}\end{array}$ & 1859.2 & 378.4 & -0.7 & 2.9 & & 3.9 \\
\hline 4 & $\begin{array}{l}\text { Right haunch } \\
60^{\circ}\end{array}$ & 1080.6 & 219.9 & -1.7 & 4.6 & 50.4 & 4.4 \\
\hline 5 & Left skewback & 1369.7 & 278.8 & -1.8 & 3.7 & & 3.8 \\
\hline 6 & Right arch foot & 789.3 & 160.6 & -4.4 & 6.2 & 5.9 & 2.9 \\
\hline 7 & Left side wall & 191.3 & 38.9 & 1.3 & 24.2 & 17.2 & 9.9 \\
\hline 8 & Right side wall & 16.2 & 3.3 & 0.4 & 282.4 & 47.2 & 40.2 \\
\hline
\end{tabular}

TABLE 9: Internal force and safety factor of primary support under parameter 2.

\begin{tabular}{|c|c|c|c|c|c|c|c|}
\hline $\begin{array}{l}\text { Monitoring } \\
\text { point }\end{array}$ & Position & $\begin{array}{l}\text { Shotcrete axial } \\
\text { force }(\mathrm{kN})\end{array}$ & $\begin{array}{l}\text { Axial force of } \\
\text { steel rib(kN) }\end{array}$ & $\begin{array}{l}\text { Steel rib bending } \\
\text { moment }(\mathrm{kN} \cdot \mathrm{m})\end{array}$ & $\begin{array}{l}\text { Shotcrete } \\
\text { safety factor }\end{array}$ & $\begin{array}{c}\text { Steel rib } \\
\text { tensile safety } \\
\text { factor }\end{array}$ & $\begin{array}{c}\text { Steel rib } \\
\text { compression safety } \\
\text { factor }\end{array}$ \\
\hline 0 & Crown & 510.4 & 115.2 & -7.6 & 8.1 & 7.4 & 3.7 \\
\hline 1 & $\begin{array}{c}\text { Deviated left } \\
30^{\circ}\end{array}$ & 1457.3 & 329.0 & -3.9 & 3.1 & & 3.4 \\
\hline 2 & $\begin{array}{l}\text { Vault deviated } \\
\text { right } 30^{\circ}\end{array}$ & 849.0 & 191.7 & -2.2 & 5.1 & & 5.9 \\
\hline 3 & Left hance $60^{\circ}$ & 1837.6 & 414.8 & -0.8 & 2.6 & & 3.8 \\
\hline 4 & $\begin{array}{c}\text { Right haunch } \\
60^{\circ}\end{array}$ & 1069.3 & 241.4 & -1.8 & 4.1 & & 5.3 \\
\hline 5 & $\begin{array}{l}\text { Left skewback } \\
\text { foot }\end{array}$ & 1349.9 & 304.7 & -2.2 & 3.3 & & 4.2 \\
\hline 6 & Right arch foot & 780.6 & 176.2 & -4.6 & 5.5 & 48.7 & 4.4 \\
\hline 7 & Left side wall & 189.0 & 42.7 & 1.4 & 21.3 & 88.2 & 16.4 \\
\hline 8 & Right side wall & 16.0 & 3.6 & 0.4 & 247.4 & 118.0 & 78.9 \\
\hline
\end{tabular}

of the steel rib appeared at the vault, which was $-7.5 \mathrm{kN} \cdot \mathrm{m}$. The corresponding safety factor value was 1.9 , which was less than the safety factor of 2.0 for the steel rib specified in code. Therefore, the solution was unfeasible.

By comparing the force characteristics of the primary support in the three options, the results showed that parameters 1 and 2 could meet the structural safety requirements, and the force of parameter 3 steel rib was unfeasible. From the perspective of economy and safety, parameter 2 was suggested.

\section{Conclusions}

Through the analysis for the deformation behavior and mechanical characteristics of support structures for Laohushan Highway Tunnel and the calculation for structure safety of primary support under different support parameters, the following conclusions can be obtained:

(1) Both crown settlement and horizontal convergence of tunnel structure mainly experienced three stages: 
TABLE 10: Internal force and safety factor of primary support under parameter 3.

\begin{tabular}{|c|c|c|c|c|c|c|c|}
\hline $\begin{array}{l}\text { Monitoring } \\
\text { point }\end{array}$ & Position & $\begin{array}{l}\text { Shotcrete axial } \\
\text { force }(\mathrm{kN})\end{array}$ & $\begin{array}{l}\text { Axial force of } \\
\text { steel rib }(\mathrm{kN})\end{array}$ & $\begin{array}{l}\text { Steel rib bending } \\
\text { moment }(\mathrm{kN} \cdot \mathrm{m})\end{array}$ & $\begin{array}{c}\text { Shotcrete } \\
\text { safety factor }\end{array}$ & $\begin{array}{c}\text { Steel rib } \\
\text { tensile safety } \\
\text { factor }\end{array}$ & $\begin{array}{c}\text { Steel rib } \\
\text { compression safety } \\
\text { factor }\end{array}$ \\
\hline 0 & $\begin{array}{l}\text { Crown } \\
\text { Crown }\end{array}$ & 510.9 & 111.4 & -7.5 & 8.7 & 2.6 & 1.9 \\
\hline 1 & $\begin{array}{c}\text { deviated left } \\
30^{\circ} \\
\text { Crown }\end{array}$ & 1462.7 & 319.0 & -3.9 & 3.3 & 19.2 & 2.5 \\
\hline 2 & $\begin{array}{c}\text { deviated right } \\
30^{\circ}\end{array}$ & 851.8 & 185.8 & -2.2 & 5.4 & 39.7 & 4.3 \\
\hline 3 & Left haunch $60^{\circ}$ & 1845.0 & 402.3 & -0.8 & 2.7 & & 3.7 \\
\hline 4 & $\begin{array}{c}\text { Right haunch } \\
60^{\circ}\end{array}$ & 1073.2 & 234.0 & 1.8 & 4.4 & & 4.2 \\
\hline 5 & Left skewback & 1356.7 & 295.8 & -2.1 & 3.5 & & 3.5 \\
\hline 6 & $\begin{array}{c}\text { Right } \\
\text { skewback foot }\end{array}$ & 783.6 & 170.9 & -4.5 & 5.8 & 5.8 & 2.8 \\
\hline 7 & Left side wall & 189.8 & 41.4 & 0.4 & 22.8 & & 22.8 \\
\hline 8 & Right side wall & 16.1 & 3.5 & 0.4 & 265.4 & 46.8 & 39.5 \\
\hline
\end{tabular}

rapid deformation, slow deformation, and stable deformation, and finally reached a relatively stable state. The primary support structure could effectively constrain the deformation of rock mass, and the support structure was also safe and reliable.

(2) The structure stress of primary support and secondary lining increases sharply at first and then tends to be stable gradually with the gradual construction of each excavation part in the tunnel. At the same time, the stress of each measuring point at the steel rib is less than the yield limit of steel frame (235 MPa). During the tunnel construction, the shotcrete was mainly subjected to compressive pressure, and the pressure at arch was greater than that at side wall. The steel rib was mainly subjected to compressive stress, and the stress of steel rib at arch was slightly larger than that at side wall.

(3) The internal force and safety factor of tunnel structure are analyzed and calculated by numerical simulation in order to obtain the reasonable support parameters of superlarge-span tunnel. The research results indicated that the support parameters including $\mathrm{H} 175 \times 175$ steel rib with a distance of $80 \mathrm{~cm}$ and C25 shotcrete with a thickness of $26 \mathrm{~cm}$ are recommended for the superlarge-span tunnel with Grade IV rock mass.

\section{Data Availability}

The data used to support the findings of this study are included within the article.

\section{Conflicts of Interest}

The authors declare that they have no conflicts of interest.

\section{Acknowledgments}

The authors would like to acknowledge the financial support provided by the National Key R\&D Program of China (grant no. 2018YFB1600100), the National Natural Science Fund
Project of China (grant no. 51978065), the China Postdoctoral Science Foundation (grant no. 2016M602738), and the Chang Jiang Scholars Program (grant no. Q2018209).

\section{References}

[1] D. Ren, D. Zhou, D. Liu, F. Dong, S. Ma, and H. Huang, "Formation mechanism of the upper triassic Yanchang formation tight sandstone reservoir in ordos basin-take chang 6 reservoir in jiyuan oil field as an examplefield as an example," Journal of Petroleum Science and Engineering, vol. 178, pp. 497-505, 2019.

[2] Q. Jiang, F. Yan, J. Wu, Q. Fan, S. Li, and D. Xu, "Grading opening and shearing deformation of deep outward-dip shear belts inside high slope: a case study," Engineering Geology, vol. 250, pp. 113-129, 2019.

[3] H. Huang, T. Babadagli, and X. Chen, "Performance comparison of novel chemical agents for mitigating waterblocking problem in tight gas sandstones," SPE Reservoir Evaluation \& Engineering, pp. 1-9, 2020.

[4] S. Chen, D. Yin, and N. Jiang, "Mechanical properties of oil shale-coal composite samples," International Journal of Rock Mechanics and Mining Sciences, vol. 123, Article ID 104120, 2019.

[5] Q. Jiang, B. Yang, and F. Yan, "New method for characterizing the shear damage of natural rock joint based on 3D engraving and 3D scanning," International Journal of Geomechanics, vol. 20, no. 2, Article ID 06019022, 2020.

[6] Y. Luo, J. Chen, Y. Chen, P. Diao, and X. Qiao, "Longitudinal deformation profile of a tunnel in weak rock mass by using the back analysis method," Tunnelling and Underground Space Technology, vol. 71, pp. 478-493, 2018.

[7] Y. Luo, J. Chen, W. Xi et al., "Analysis of tunnel displacement accuracy with total station," Measurement, vol. 83, pp. 29-37, 2016.

[8] Y. Luo, J. Chen, W. Xi, and P. Zhao, "Application of a total station with RDM to monitor tunnel displacement," ASCE Journal of Performance of Constructed Facilities, vol. 31, no. 4, Article ID 04017030, 2017.

[9] J. Chen, Q. Wang, J. Guo, and Y. Luo, "Mechanical properties and acoustic emission characteristics of karst limestone under uniaxial compression," Advances in Materials Science and Engineering, vol. 2018, Article ID 2404256, 14 pages, 2018. 
[10] X. Xue, J. Zhang, and X. Zhou, "Reliability evaluation of water-rich loess tunnel with lining crack based on extension theory," Advances in Civil Engineering, vol. 2019, Article ID 8267406, 10 pages, 2019.

[11] Ministry of Land, "Transport and maritime affairs," Road Design Manual, vol. 6, 2010.

[12] Korea Highway Corporation Highway Custom Tunnel Design Guide 2009, 2009.

[13] China Communications Press, Specifications for Design of Highway Tunnels: (JTG 3370. 1-2018) [S], China Communications Press, Beijing, China, (in Chinese), 2018.

[14] Z. Hu, K. Du, J. Lai, and Y. Xie, "Statistical analysis of influence of cover depth on loess tunnel deformation in NW China," Advances in Civil Engineering, vol. 2019, Article ID 2706976, 12 pages, 2019.

[15] A. Jiang, P. Li, and H. Shi, "Shallow depth of the tunnel excavation response research based on CRD method," Procedia Engineering, vol. 15, pp. 4852-4856, 2011.

[16] D. Koutsoftas, "State of practice: excavation in soft soils," in Proceedings of Geotechnical Engineering State of the Art and Practice, American Society of Civil Engineers, Oakland, CA, USA, pp. 678-728, March 2012.

[17] J. Lai, J. Qiu, H. Fan et al., "Fiber bragg grating sensors-based in situ monitoring and safety assessment of loess tunnel," Journal of Sensors, vol. 2016, pp. 1-10, Article ID 8658290, 2016.

[18] J. Chen, W. Liu, L. Chen et al., "Failure mechanisms and modes of tunnels in monoclinic and soft-hard interbedded rocks: a case study," KSCE Journal of Civil Engineering, vol. 24, no. 4, pp. 1357-1373, 2020.

[19] W. Liu, J. Chen, L. Chen, Y. Luo, Z. Shi, and Y. Wu, "Nonlinear deformation behaviors and a new approach for the classification and prediction of large deformation in tunnel construction stage: a case study," European Journal of Environmental and Civil Engineering, pp. 1-29, 2020.

[20] S. O. Choi and H.-S. Shin, "Stability analysis of a tunnel excavated in a weak rock mass and the optimal support system design," International Journal of Rock Mechanics and Mining Sciences, vol. 41, no. 3, pp. 537-881, 2004.

[21] S. Hussain, Z. U. Rehman, and N. Mohammad, "Numerical modeling forengineering analysis and designing of optimum support systems for headrace tunnel," Advances in Civil Engineering, vol. 2018, Article ID 7159873, 10 pages, 2018.

[22] A. Kaya and A. Sayın, "Engineering geological appraisal and preliminary support design for the Salarha Tunnel, Northeast Turkey," Bulletin of Engineering Geology and the Environment, vol. 78, no. 2, pp. 1095-1112, 2017.

[23] S.-M. Gao, J.-P. Chen, C.-Q. Zuo, W. Wang, and Y. Sun, "Structure optimization for the support system in soft rock tunnel based on numerical analysis and field monitoring," Geotechnical and Geological Engineering, vol. 34, no. 4, pp. 1089-1099, 2016.

[24] Q. Jiang, G. Su, X.-T. Feng, G. Chen, M.-Z. Zhang, and C. Liu, "Excavation optimization and stability analysis for large underground caverns under high geostress: a case study of the Chinese Laxiwa project," Rock Mechanics and Rock Engineering, vol. 52, no. 3, pp. 895-915, 2019.

[25] J. Wang, Q. Huo, Z. Song, and Y. Zhang, "Study on adaptability of primary support arch cover method for large-span embedded tunnels in the upper-soft lower-hard stratum," Advances in Mechanical Engineering, vol. 11, no. 1, pp. 1-15, Article ID 168781401882537, 2019.

[26] C. Huang, "Optimization of support parameters for flat super large section highway tunnel structure," in Proceedings of the
2008 National Symposium on Tunnel Monitoring Measurement and Counter-Analysis, Chongqing University Press, Chongqing, China, pp. 64-70, 2008.

[27] F. Hou, Deformation Mechanism and Stability Control of Large Span Horizontal Layered Surrounding Rock Tunnel, Shandong University, Jinan, China, 2019.

[28] B. Wu, Upper Limit Analysis and Support Parameter Optimization of Two-Way Eight-Lane Small Clear Distance Highway Tunnel Support, Central South University, Hunan, China, 2006.

[29] P. L. He, "Research on the orthogonal test of tunnel support parameters based on the finite element strength reduction method," Applied Mechanics and Materials, vol. 170-173, pp. 1533-1537, 2012.

[30] X. Han, M. Sun, W.-J. Li, and Y.-Q. Zhu, "Optimization of section shape and support parameters of tunnel under complicated conditions," Rock and Soil Mechanics, vol. 32, no. 1, pp. 725-731, 2011, (in Chinese).

[31] W. Min, J. Lai, J. Qiu, and Y. Zhang, "Numerical analysis of excavation scheme of four lane long-span shallow buried loess tunnel," Journal of PLA University of Science and Technology (Natural Science Edition), vol. 18, no. 01, pp. 36-42, 2017.

[32] J. Chen, S. Yang, and Y. Luo, "Field test research on elimination of systematic rock bolts in weak rock tunnel," Rock and Soil Mechanics, vol. 32, no. 1, pp. 15-20, 2011, (in Chinese).

[33] Y. Luo, J. Chen, H. Wang, and P. Sun, "Deformation rule and mechanical characteristics of temporary support in soil tunnel constructed by sequential excavation method," KSCE Journal of Civil Engineering, vol. 21, no. 6, pp. 2439-2449, 2017.

[34] L. M. Massone and F. Nazar, "Analytical and experimental evaluation of the use of fibers as partial reinforcement in shotcrete for tunnels in Chile," Tunnelling and Underground Space Technology, vol. 77, pp. 13-25, 2018.

[35] Z. Wu, Study on Suitability of Flat Ratio and Support Parameter of Large Section Highway Tunnel, Southwest Jiaotong University, Sichuan, China, 2017.

[36] C. Gong, W. Zhang, and Y. Yang, "Discussion on structural design and construction schemes for four-lane section in each separated hole of highway tunnels," Highway, no. 06, pp. 177-182, 2004.

[37] S. Zhong, Unified Research Theory of Concrete-Filled Steel Tube, Tsinghua University Press, Beijing, China, 2006.

[38] W. Ma, Q. Xu, J. Li, and Y. Liu, "Investigating the numerical modelling of the construction excavation of an actual super shallow large-span tunnel," World Multidisciplinary Civil Engineering - Architecture - Urban Planning Symposium - WMCAUS, vol. 245, no. 3, Article ID UNSP032023, 2017.

[39] J. Sun and P. Wang, Analysis of Underground Structure Finite Element Method, Tongji University Press, Shanghai, China, 1988.

[40] S. Jiang, L. Huang, and X. Hu, "Design and study of highway tunnel with super -large cross section," Chinese Journal of Underground Space and Engineering, vol. 1, no. 1, pp. 54-61, 2005.

[41] F. Jin and Q. Qian, "Simulation of three-dimensional tunnel excavations," Chinese Journal of Rock Mechanics and Engineering, vol. 159, no. 3, pp. 193-200, 1996. 